
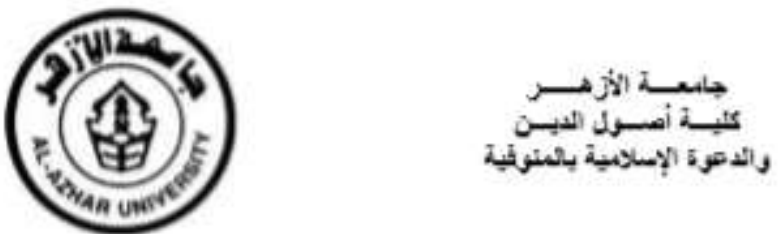

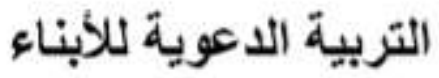<smiles>[13CH3]</smiles>

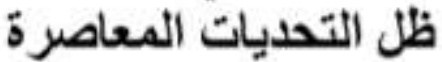

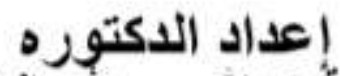

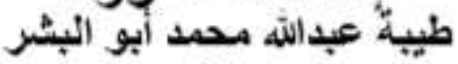

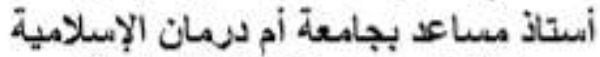

كلية الدعثة والثقافة الإسبلامية الإنية

$$
\text { مسترة من }
$$

حوائية كلية أصول الثين والثعوة بالمنوفية العدد الثلامن

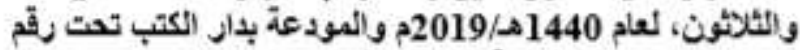

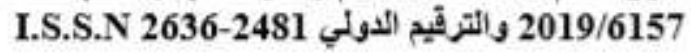

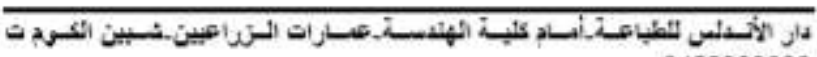





\section{tad unito}

\section{التزبية الدموية للأبناء في ظل التمديات المعاصرة}

الحمد الله نحمده ونستعين ونستغفره ونعوذ باله من شرور أنفسنا ومن سيئات أعمالنا من يهده الله فلا مضل له ومن يضلل فلا هادي لله، وأشهد أن لا اله إلا لا له

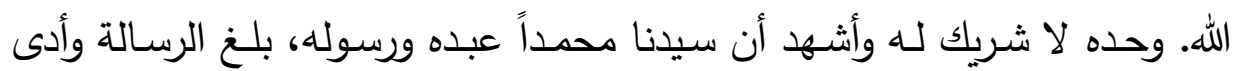
الأمانة ونصح الأمة، وجاهد في الله حق جهاده حتى تركنا على المحجة البيضـاء

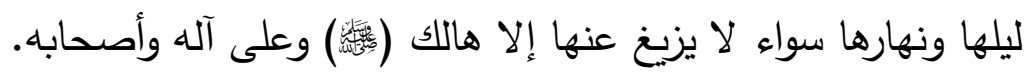

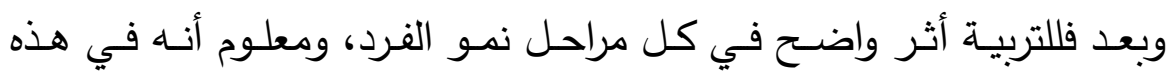
المراحل تتغير سلوكيات الفرد من حال إلى حال بطرق مختلفة وفلسفات تربويـة عالية، وقد ترتقي مفاهيمه وأخلاقه ويتحول سلوكه إلى الأفضل أو الأردأ. لهذا جاء البحث لتبني هذه القضية متمثلاً في أربعة مباحث، المبحث البث الأول المعنى اللغوي والاصطلاحي الذي يتضمن معنى التربية وهي تتشئة إنسان مسلم متكامل في جميع نواحيه من صحية وعقلية وعقائدية، وروحية.... إلخ بالإضـافة إلى مفهوم الأبناء ومفهوم الدعوة إلى الله وأما المبحث الثاني فتحدث عن القواعد الأساسية للتربية من إيمان وأخلاق وتربية جسدية وعقلية واجتماعية، أما المبحث

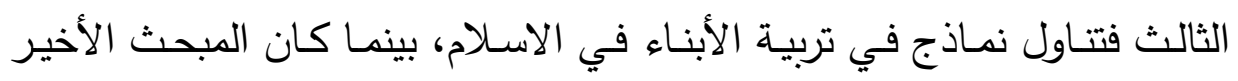
للحديث عن تحديات التربية الدعويـة المعاصـرة وطرق مواجهتها دعويـاً، وأخيراً النتائج والتوصيات.

الكلمات الافتتاحية: التربية - الأبناء - التعليم - التحديات المعاصرة

د. طيبة وبد|الاه مصمد أبه البشئر

أستاذ مساعد بجامعت أم درمان الإسعلاميتية

كليت الدهوة والثقافت الإسلاميت

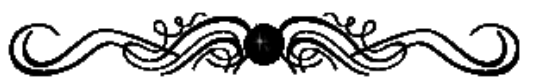




\section{ABSTRACT \\ Advocacy for Children in Education Under the Contemporary Challenges}

Praise is to Allah we praise him and we ask him and we forgive him and seek refuge in Allah from the evils of ourselves and from the disadvantages of our deeds, who Allah may guide him no one mislead him, and who Allah mislead him no one guide him, and testify that there is no God but Allah. Alone and I testify that Muhammad Abdu and his messenger, reached the message, do the honesty and advised the nation, and struggled in the right to jihad until we left on the white channel night and day, whether it is only the mortal, peace be upon him and his companions. Education has a clear impact at every stage of the growth of the individual, and in these stages slow the individual is from case to case in different ways and a high educational philosophy, and his concepts, morals and behavior may be elevated to the best or to the bad.

This is why the search for the adoption of this case is represented by four detectives, the first discourse of linguistic and terminological meaning which includes the meaning of education and is the upbringing of a Muslim person integrated in all aspects of health, mentality, ideology, and spiritual... In addition to the concept of the children and the concept of invited to Allah and the second discourse talked about the basic rules of education of faith and morals and the physical and mental education and social, and the third discourse on the education of children in Islam, while the last discourse talked about the challenges of the education of invited The contemporary and the ways to confront it, and finally the results of the Holy Quran and the Sunnah of the Prophet, the origins of the curriculum of the case for education and recommendations to follow the approach of the lawsuit in the upbringing of the Islamic children.

Key Words: Advocacy - Children - Education - The Contemporary Challenges.

\section{Dr. Tyba Mohamed Abdullah Abu El Bashar Assistance Professor, Omdurman Islamic, University of Da'wa and Islamic Culture E mail : a7medelmubarak@yahoo.com}




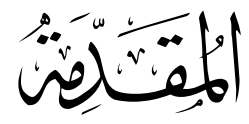

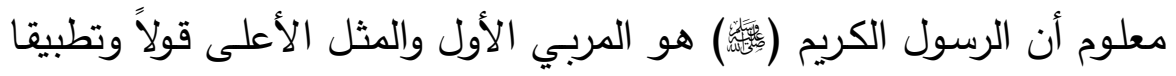

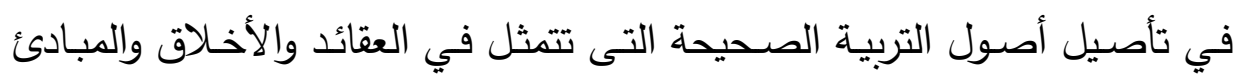
والعادات والتقاليد وقد حمل المسئولية لكل مسلم إلى أن يلقى ربه (كلكم راع وكلكم ('). مسؤول عن رعيته) ولذا فإن المهام التربوية تقع على المربين بكل الطبقات والقيام بالرعاية والتربية والتوجيه إلى المثل الأعلى والتمسك بالفضائل كنلك.

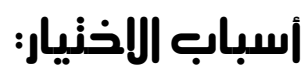

ما أصـاب الكثيرين من أبناءنا وشبابنا نحن المسلمين في عقيدتهم وأخلاقهم وسلوكهم من فساد ودمار في العصر الراهن، فرض علينا مراجعة قواعدنا التربوية.

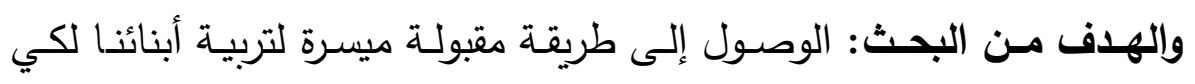

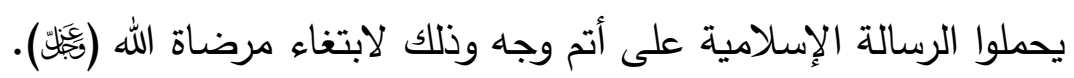

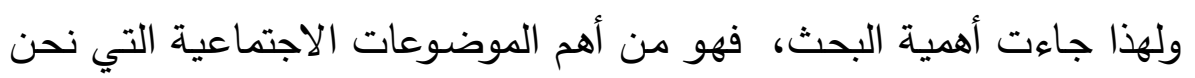

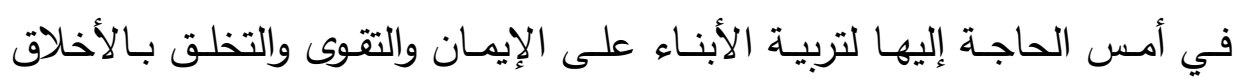
الفاضلة. المنهج المتبع للبحث: سوف يتبع البحث عدة مناهج هى المنهج التاريخي والمنهج الوصفي والمنهج التحليلي.

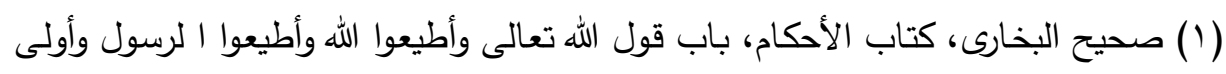
$-11 \mathrm{~V}$ 


\section{مشكلة البحث: في عدة نساؤلانه:}

انحراف الأبناء والتزايد المستمر في ذلك.

" ما هي القواعد الأساسية للتربية الإسلامية الصحيحة.

هل لنماذج التربية الدعوية أثر في تربية أبناء اليوم.

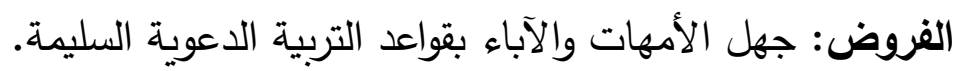

العولمة والتأثير الثقافي في الأبناء. - ضعف الإباء لعوعاعان والبعد عن الدين لدى كثير من الوالدين.

\section{|لمر|سانه |لسابقة:}

من الدراسات السابقة في هذا الموضوع، بحث بعنوان: تربية الطفل في القرآن

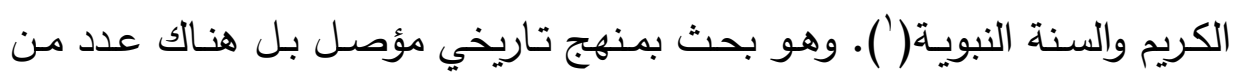

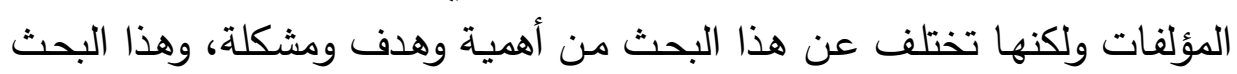

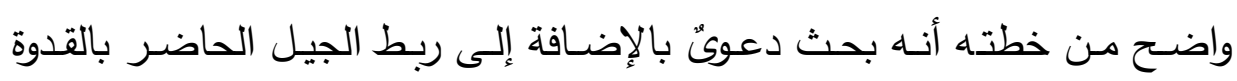
الأصيلة.

\section{|لنبويب: الاصن:}

المبحث الأول: المعنى اللغوي والاصطلاحي لكل من التربية، والأبناء، والدعوة. المبحث الثاني: القواعد الأساسية للتربية الدعوية وأهميتها. المبحث الثالث: نماذج للتربية الدعوية للأبناء في القرآن والسنة. المبحث الرابع: تحديات التربية المعاصرة وطرق معالجتها دعوياً. وأخيراً أهم الننْائج:

التي يمكن إجمالها فيما وضـح القرآن الكريم والسنة النبويـة من أصول المنهج التربوي وكيف وحدد أساسياته وطرق اتباعه. فما على المربيين إلا الاقتداء بالمنهج الإسـلامي في تربية أبنائهم مراعاة لحق الله تعالى عليهم في تربيتهم.

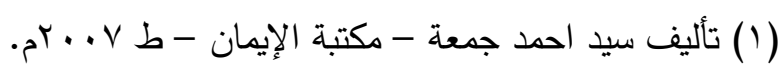




\section{البمش الأومل}

\section{الامنى الاغمي والاهمالامي لاتزبية والأبناء والدموة}

\section{|لتزبية لفة:}

التربية لغة: من رب، والرب يطلق على الله تبارك وتعالى معرفاً بالألف والتلام

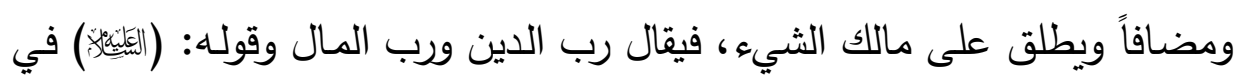

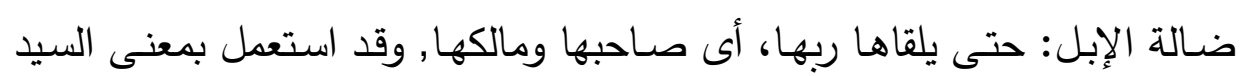

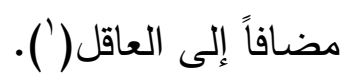

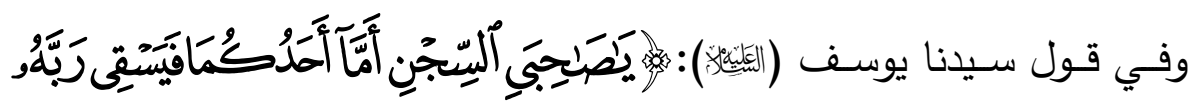

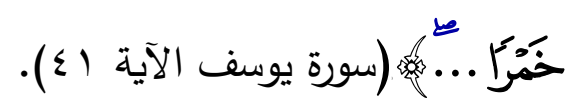
وقيل للحاضنة ربة وربيبة، والجمع ربائب، وجاء ربيبات على لفظ الواحد. ربا يربي إرباء وتربية فهو مربي والمفعولُ مربَّى(').

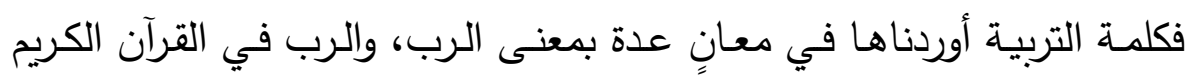

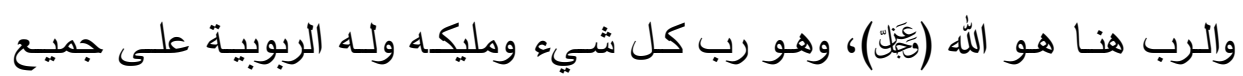
الخلائق لا شريك له ولا يقال الرب في غير الله إلا بالإضافة. وهو ربه

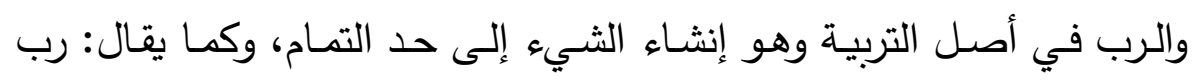

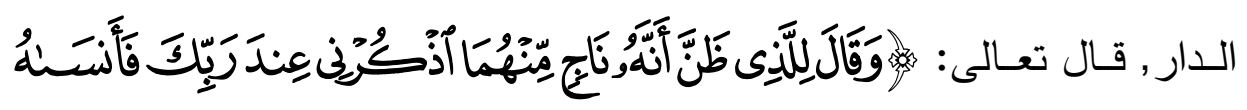

( (1) المصباح المنير في غريب ع / الثرح الكبير ، احمد بن محمد على الفيومى، المكتبة

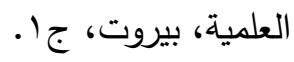

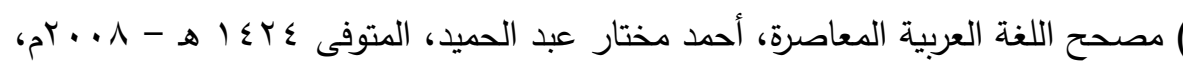

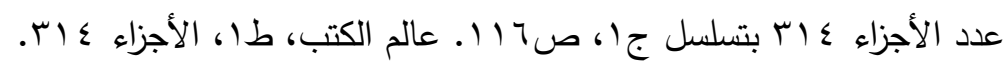




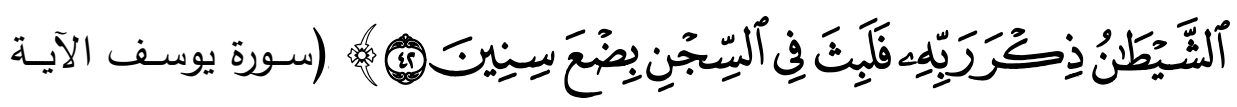
. $(\leqslant r$

ونجد أيضاً تحت أصل رب يربى كلمة ربائبكم التي وردت في قوله تعالى:

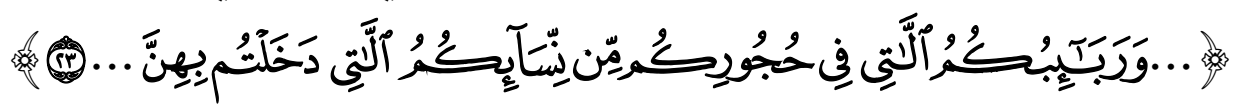

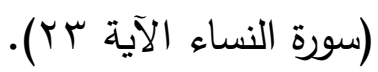
وربة: من أشراط الساعة (أن تلد الأمة ربتها)، الرب يطلق في اللغة على الكى

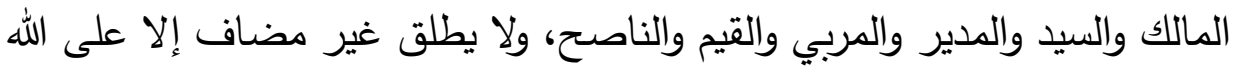

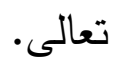

كرجل ذهب يربأ أهله، أي يحفظهم من عدوّم.(')

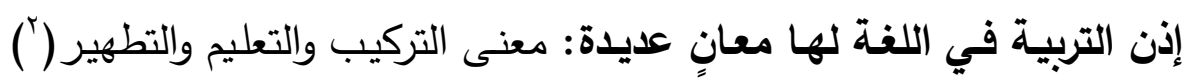

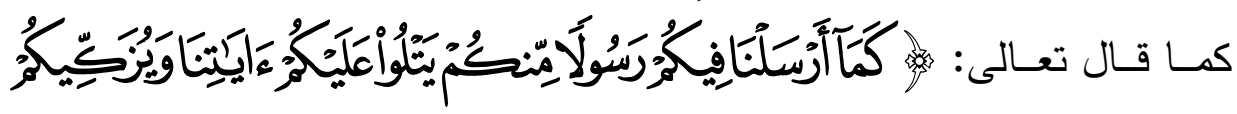

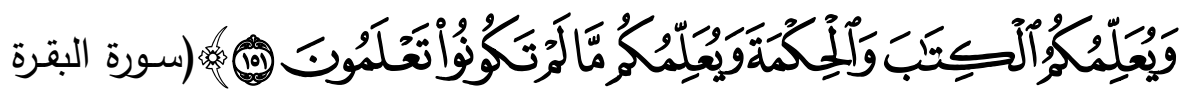
الآية: (10) (10).

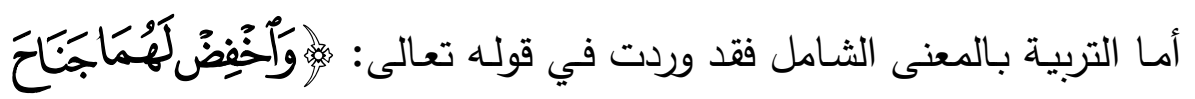

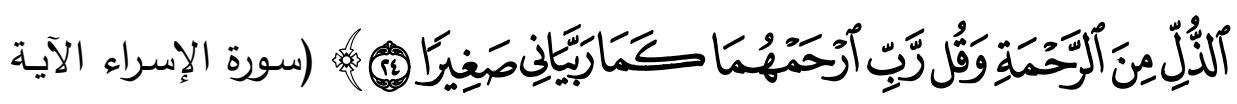

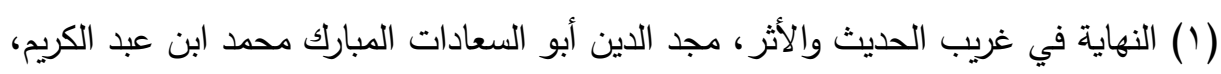

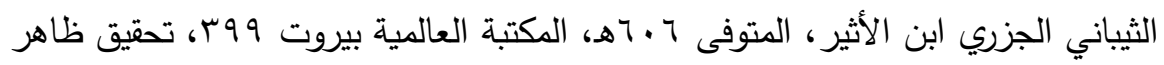
الزاوي - محمد بن محمد الطناس جن.

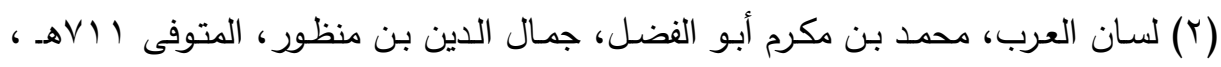

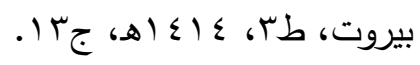




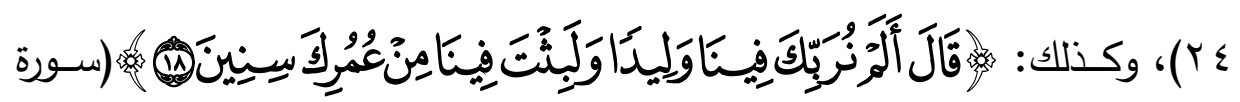

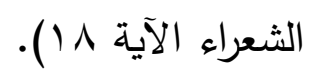

\section{|لتزبية|صطالحا:}

التربية في اصطلاح السدلف: تبليخ الثيء إلى كماله شيئاً فثيئاً، أمـا في اصطلاح المعاصرين فالتربية هي تتشئة إنسان مسلم متكامل في جميع نواحيه المختلفة من الناحية الصحية والعقلية العقدية والروحية والأخلاقية والإبداعية، وفي جميع مراحل نمـوه في ضـوء المبادئ والقيم التي أتى بهـا الإسـلام وفي ضـوء ولاء أساليب وطرق التربية الصحيحة:

واتفق علمـاء المسلمين على أن التربية عملية تحقيق النمو المتزن المنسجم

لجميع استعدادات الفرد النفسية والعقلية والخلقية حتى يصل إلى كماله.(') وفي تعريف أشمل: التربية هي تربية الفرد وتتميته تتمية شاملة متكاملة من جميع الجوانب (الجانب الروحي والعقلي والنفسي والبدني والاجتماعي) ويجب

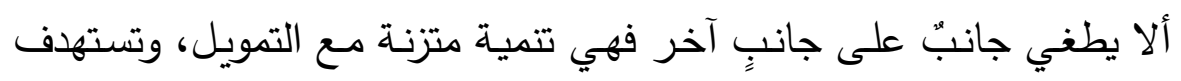

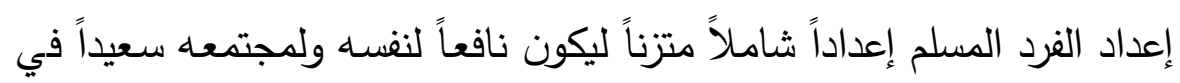

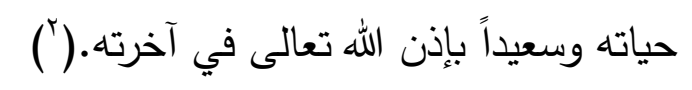

مفهوم الدعوة: هى من دعا يدعو فهو داعية، والتاء للمبالغة وهى ترجع إلى لى

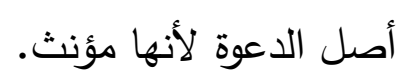

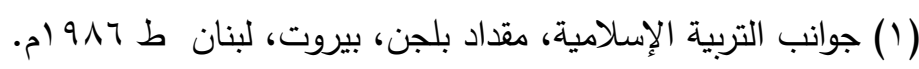

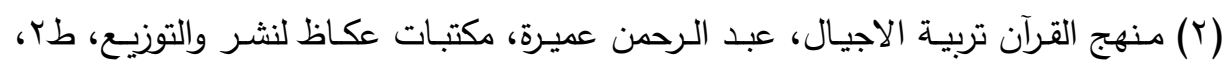
.01911 


\section{|صطلإحياً |خنلفنه |لنمريفانه:}

ا ـ البعض نظر إليها بأنها تبليغ وبيان في قوله تعالى:

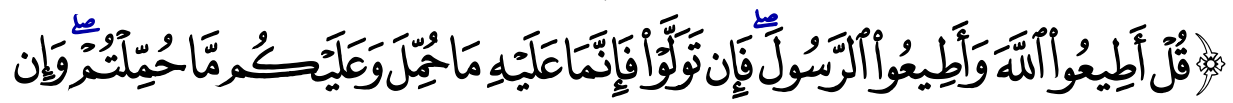

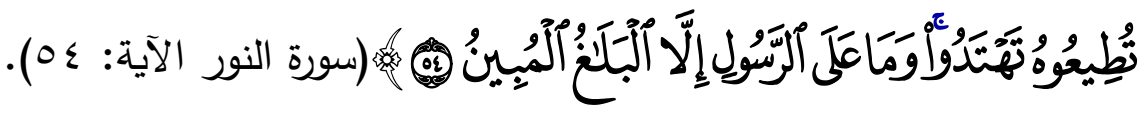

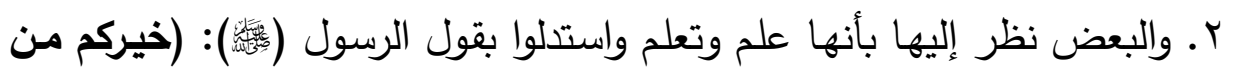

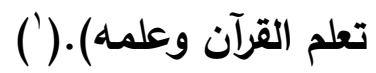

r. والآخر مزج بين مفهوم الدين والدعوة وهو قول الأستاذ محمد الراوي حيث قال هي: (الضوابط الكاملة للسلوك الإنساني وتقرير الحقوق والواجبات). ع. وتعريف آخر عرفه الثديخ محمد الخضر حيث قال هي: (حث الناس على الخيـر والهُدى والأمـر بـالمعروف والنهـي عـن المنكـر ليفوزوا بالسعادة العاجلـة والآجلة).

إذن التعريف الأثمل لكلمة الدعوة الحركية هو: (مجموعة القواعد والأصول التي يتوصل بها الداعية إلى تبليغ الإسـلام للناس وتعليمه وتطبيقه):

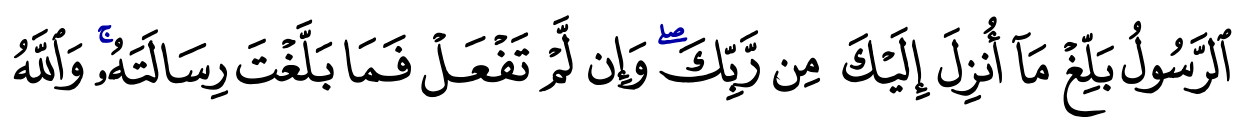

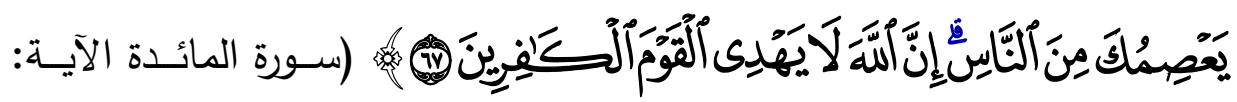
$\cdot(7 \mathrm{~V}$

صحيح البخارى، كتاب فضائل القرآن، باب خيركم من تعلم القرآن وعلمه، حديث رقم 


\section{الأبناء لفة:}

الابن وأصله بنـو، فالذاهب منـه كالـذاهب من أب أو أخ ويقـال: ابن بين

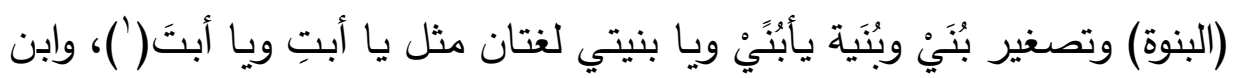

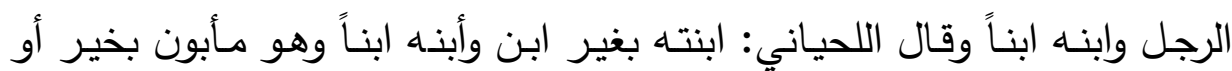
بشر

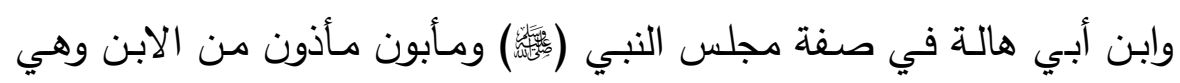

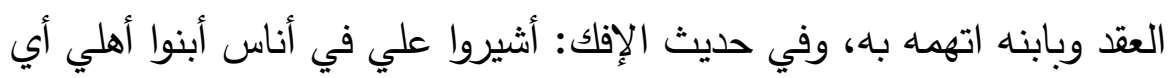

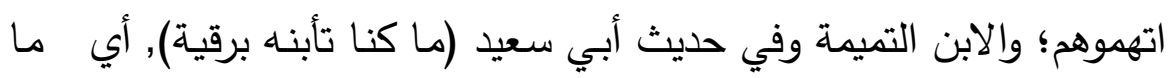
كنا نعلم أنه يرقى فتعجبه بذلك. والبنو عند بعض أهل العربية: أصل أبناء الابن والنسبة إليه بذوي، وكذلك الكيك

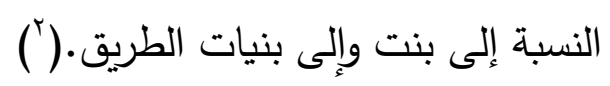
وقد وردت كلمة الأبناء في القرآن الكريم في عدد كثير من الآيات.

\section{الأبناء |صطلإحاً:}

البنوة هو من الابن وهو حيوان يتولد من نطفة شخص آخر من نوعه.(")

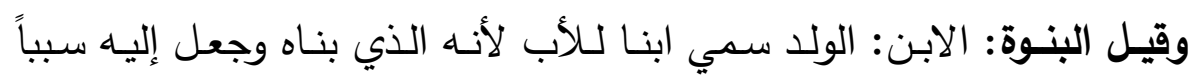

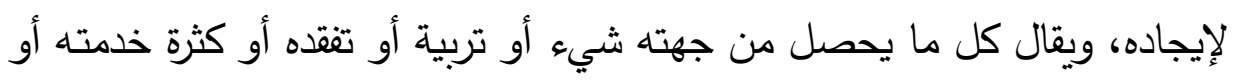

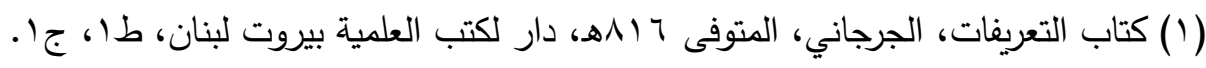

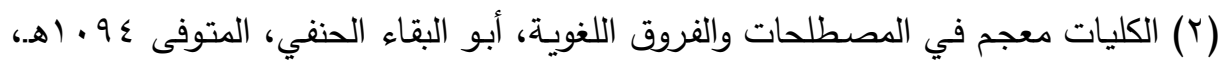
المحقق عدنان درويش محمد المصرفي، مؤسسة الرسالة بيروت.

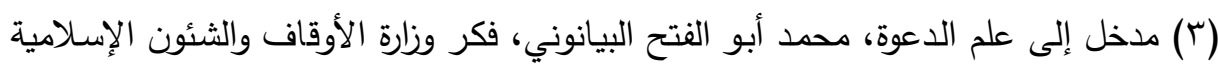
$-1 r^{2}-$

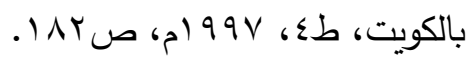


قيامه بأمره. ابن نحو ابن السبيل للمسافر ، وابن الحرب للمجاهد، وفلان ابن بطنه وابن يومه إذا لم يفكر في غد. والبنوة لا تدل على كونـه بالواو كالفتوة والفتى ونسبة الأب بالابن والابن بما يبنِ عليه. (ونادى نوح ابنه) أي ابن امرأته ويسمى الملك رعيته أبناء والأنبياء من بني

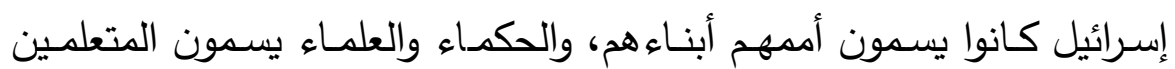

$$
\text { منهم أبناءهم.(') }
$$

وقد يكنى الابن في بعض الأشياء بمعنى الصـاحب كقولهم ابن عربية وابن

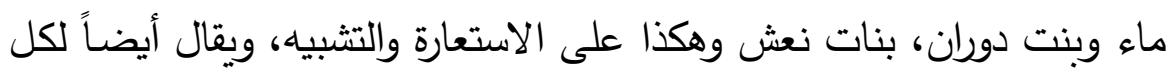
ما يحصل من جهة شيء أو تربية أو أكثر خدمته أو قيامه بأمره أو توعيته

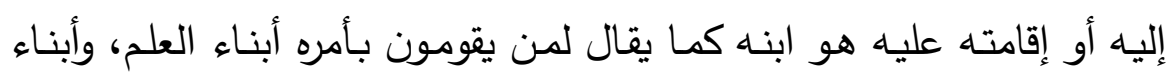
السبيل وأبناء الدنيا. فـالمعنى الحقيقي لابن: هو الصبي وكذا للولد منفرداً وجمعاً ولكن العرف سمى الولد حقيقة في ولد الصلب واستعمال الابن والولد في الابن والابن مجاز ولهذا صح أن يقال (إنه ليس ولاي بل ولا ابني).

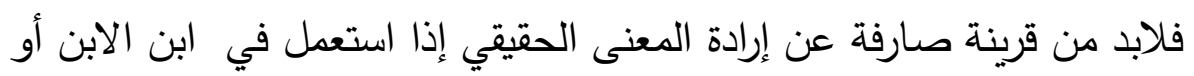
في معنى شامل كما في قوله تعالى: (يا بني آدم) فورود الخطاب قرينة صارفة إنة

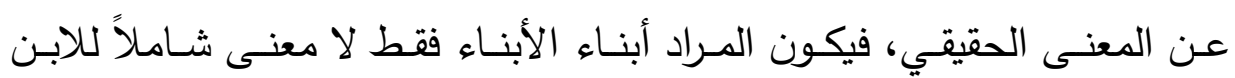
الأصلي وابن الابن، وهذا لا يدل على صحة استعمال لفظ الولد، والمعنى الثامل للأولاد من الصلب وأولاد الأبناء والحق في أن يطلق الابن على ابن الابن لا لإنى 
يستلزم إطلاق الولد على ابن الابن، فإن حكم لفظ الابن مغاير لحكم لفظ الولد في أكثر المواضع.

فيتناول لفظ الابن ابن الابن وإنما يدل على تتاول الولد لابن الابن أن لو كان

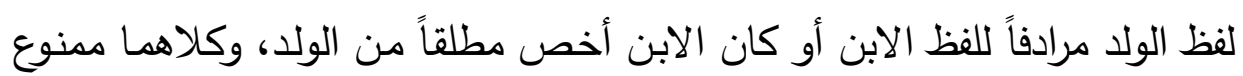
لأن الأولاد تطلق عرفاً على أولاد الأبناء، بخلاف الأبناء وكذا تطلق عرفاً بدخول الحفيدة، فبينهما عموم وخصوص وجهي فلا يلزم من تناوله في معنى واحد قال تعالى: (يذبحون أبناءكم) وهنا المراد الذكور خاصة.(')

\section{(C)}

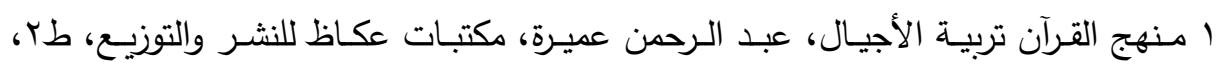
م) 911 


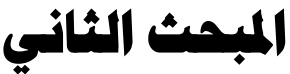

\section{القواعد الدومية لاترّبية وأهميستها}

القاعدة الأساسية للتربية هي الرجوع إلى المصادر الأصلية المتمثلة في الكتاب والسنة والإجماع والقياس, لترسيخ العقيدة والتتمية والفكر السلي. لإعداد جيل واعد يعمل في قلبه وعقله على تمثيل مبادئ منهج وسلوك في حياتهم ليكونوا دعاة

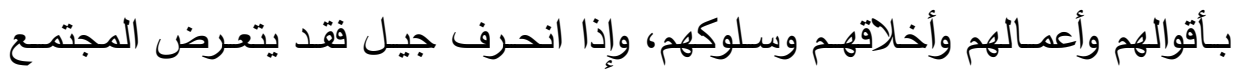
الإسـلامي للتفكك والانحـلال وفقد الأهداف، كمـا تعرضـت لـه الدعوات السـابقة،

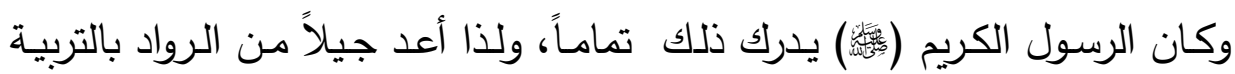

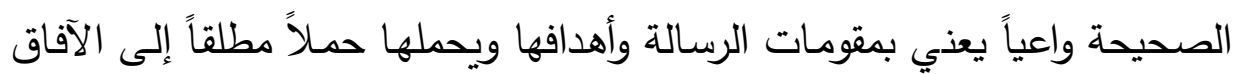
عبر تتابع الزمان والمكان (فالرسالة عالمية لتعمير الحياة لتعيش الأمـة في محبة وتفاهم وتعاون في ظلال الحق والعدل والخير والحرية). ومن أهم المبادئ التي حرص عليها الإسـلام في جميع المجالات التدرج في مجالات التربية خاصـة، وبذلك جاءت السنة القولية والعملية، والتدرج في التعليم أيضـاً، وكما في تقصير الصـلاة من أربعـة ركعات في الحضر الى ركعتين في السفر , وكما حُرم الخمر بالتدريج والربا وغيرها فمنهج التدرج الحكيم يسهل على المتلقين امتثال الأوامر واجتاب النواهي في غير حرج.

فمفهوم المنهج التربوي الدعوي هو مبادئ وخصائص تربوية دعوية سليمة. وهو ما جاء به القرآن الكريم، يوجه الآباء ويأمرهم بحماية أبنائهر من الفسوق

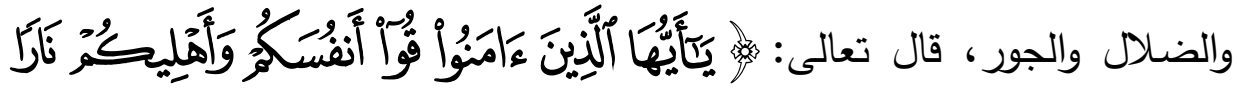

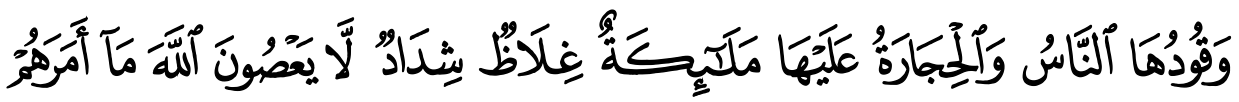

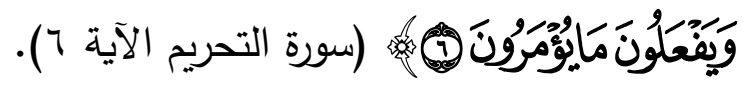


فالقرآن الكريم بتوجيهاتـه السـامية جـاء ليربي الفرد المسلم في جميع مراحل

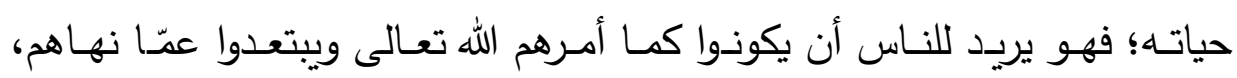
ويتعاونوا على البر والتقوى ولا يتعاونوا على الإثم والعدوان ويدعوا إلى الله علي

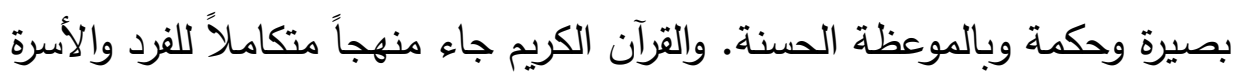
والمجتمع فلم يقتصر على العبادة دون السلوك ولم يختص بالفرد ويترك المجتمع، فهو منهج ملحوظ في نواميس الفطرة التي تعرف بالنفس البشرية في أطوارها

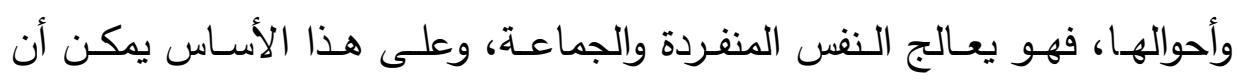

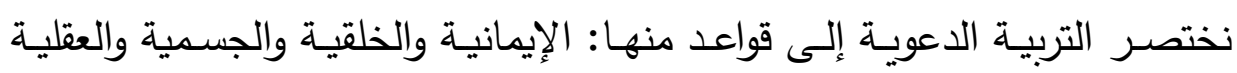
والاجتماعية والتي يمكن تفصيلها فيما يلي.

\section{أولًا: التربية الإيهانية:}

أول أبواب الإيمان هو الإيمان بالله وحده لا شريك له وأن سيدنا محمداً عبده ورسـوله. وغرس الاعتزاز بهذا الشـعور هو عمـل موثوق مـتقن بقناعـة روحيـة

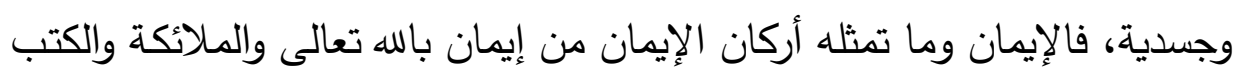

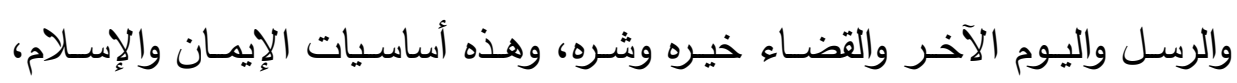

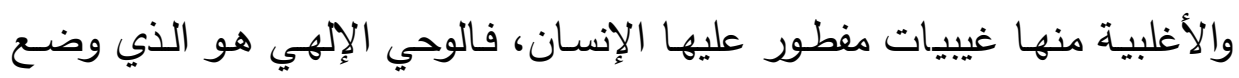
أصول خصائص المنهج التربوي الإسلامي وحدد الأساسيات التي لابد منها لبيان معالم الشخصية الإسلامية('). أمـا التربية الدعويـة فنعني بها الدعوة إلى تطبيق مـا جاء في أركان الإيمان

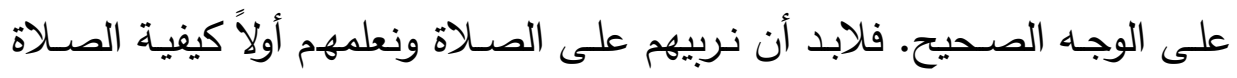

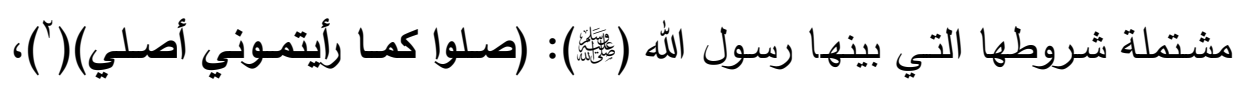

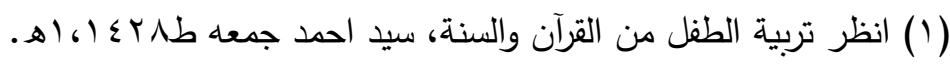

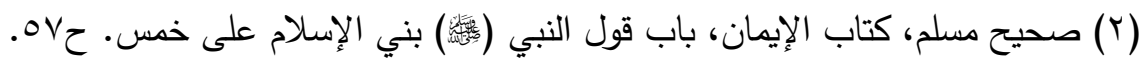


والزكاة التي هي الصدقة الواجبة على كل مسلم مستطيع لأنها تطهير النفوس من الثـح والبخل والحقد والحسد، وتطهر المـال وتقي المجتمـع مـن الجرائم والسرقة

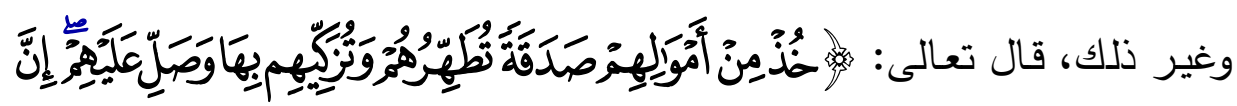

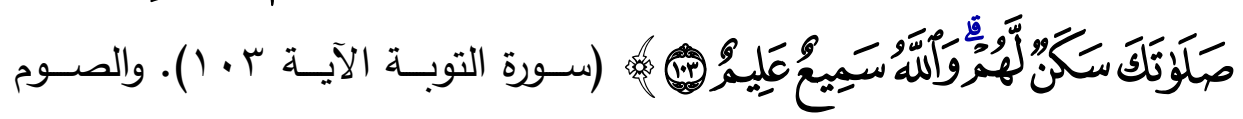
وتعليم درجات الصوم وأن الله قد فرض لهم وقت الصوم وشهر الصوم. وما يحل للصائم وما يبطل صيامه وفوائد ومزايا الصيام من الناحية البدنية والروحية، قال

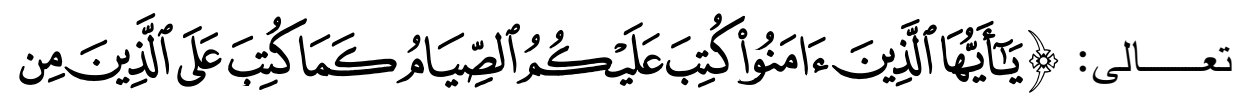

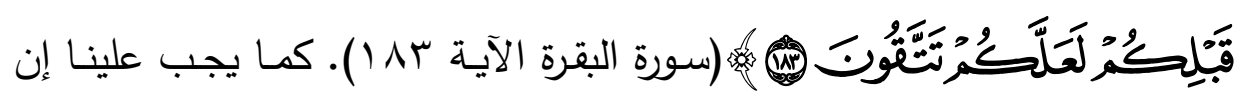
نعلم أبناءنا أن الله قد فرض الحج على كل إنسان أن يحج البيت مرة أو في العمر

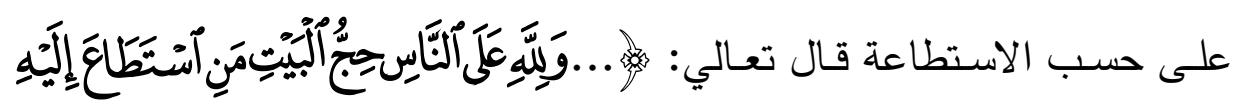

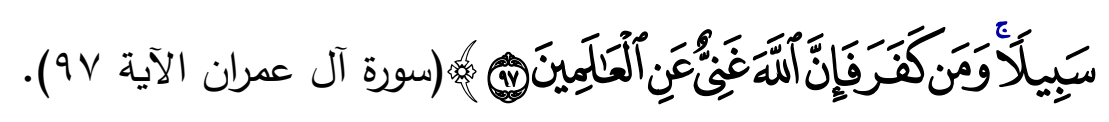
ومع العمل بأركان الإسـلام والإيمان نربي أبناءنا على الإيمان السليم الراستخ

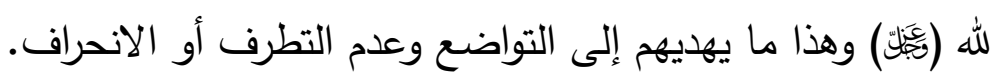

\section{व्रै⿴囗十}




\section{ثانياً: التزبية الأخلاقية:}

التربية الأخلاقية هى التي تقوم على أساس العقيدة وبيان أثر العقيدة في سلوك

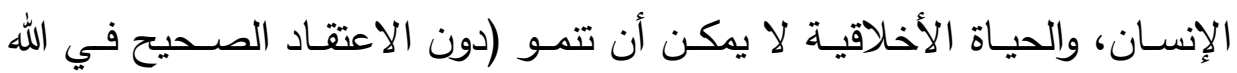

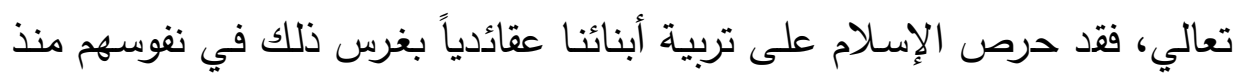

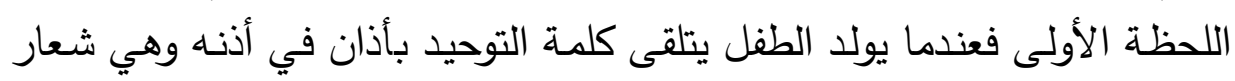

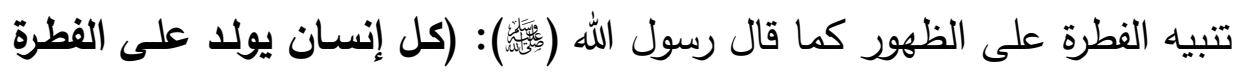

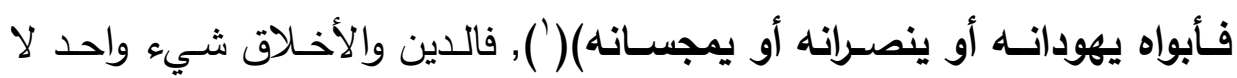

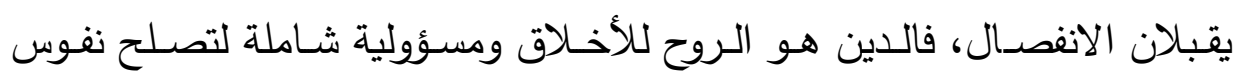

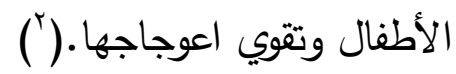

ويجب تربيتهم على الاستقامة وحب الخير وعلى الصـدق والأمانـة وإغاثـة

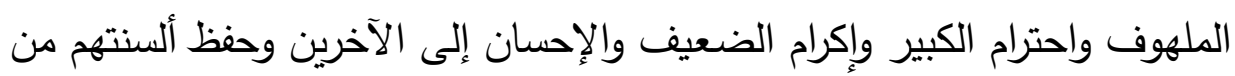
الثتائم وفسـاد الخلق، وتربيتهم على الثرف والثرام والعفة والابتعاد عن أسـاليب الكفر واللعن وتعويدهم الصدق قولا وعملاً. (")

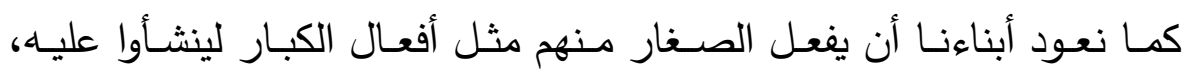
والبنات مثل أفعال النساء وولا نشبه الصبية بالبنات ولا البنات بالصبية كما هو

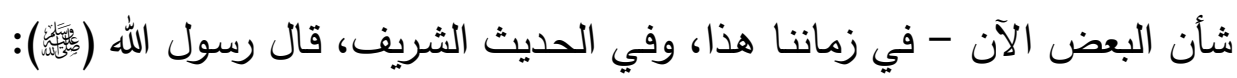

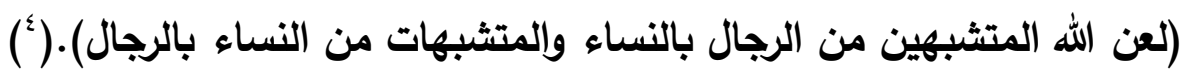

(1) سنن الترمذي كتاب القدر، باب ما جاء في كل مولود يولد على الفطرة ج؛، وفي البخاري

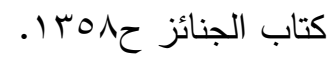

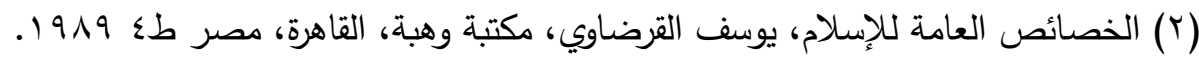

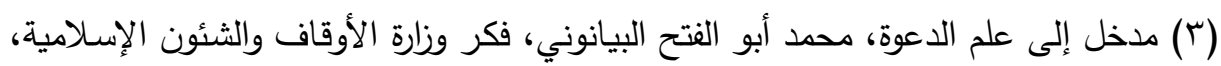

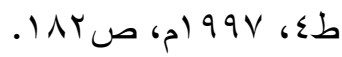
صحيح البخاري، كتاب اللباس، باب المتثبهون بالنساء والمتثبهات بالرجال، خء جل 
وأن تكون هنـاك حشمة في اللبس سـواء كانـت امـرأة أو رجـلاً وذلك بـأن يكون اللباس لباساً دينياً ساتراً يميّز الرجل عن المرأة.

\section{ثالثاً: التزبية الجسسدية والعقلية:}

التربية الجسدية والعقلية هي السبيل لتكوين الإنسـان الصـالح، وهي مظاهر الصـحة والحيويـة والنشـاط وكفاءات الحركة والمحافظـة عليها، لكي ينشـأ الأولاد على قـوتهم الطبيعيـة؛ فالتربيـة الجسـية واجـب إيمـاني إسـلامي لأنها السـبب المباشر في أداء العبادات بالوجـه الصـحيح، فالمؤمن القوي خير وأحب إلى الله تعالي من المؤمن الضعيف. ومن الأسباب الفطريـة للطفل السليم تجنب زواج الأقارب بقدر الإمكان، لأن الطفل يرث الصفات الفطرية وقد ثبت في علم الوراثة أن الطفل يكون ضعيفاً في

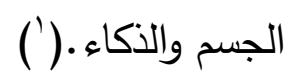

فالتربية لا تقف بل تستمر من الحمل إلى أن يولد الطفل وفي مراحل نموه في الحياة، وقد اكتشف العلم الحديث بعض أمراض الإعاقـة الجسمية والتي أغلبها تعرض الأم لبعض الأمراض، كالزهري والحصبة والأنيميا والمخدرات والعقاقير في الثهور الأولى للحمل، فوقاية الطفل مسؤولية الأم والأب والطبيب إن وجد. وبعد الولادة واجب عليهح جميعاً العناية والاهتمام بالطفل عناية تامة والاهتمام

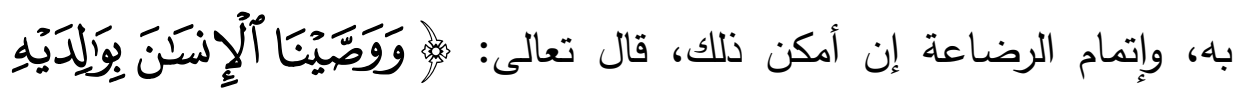

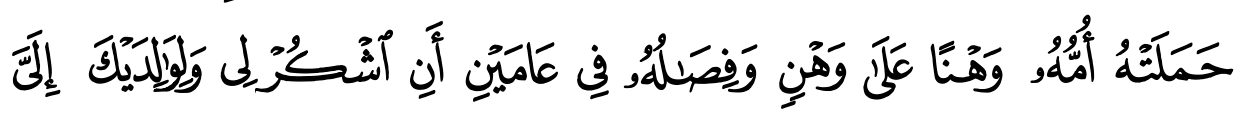

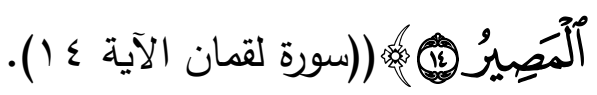

(1) الثقافة العربية وأزمة العولمة، أحمد مجدي حجازي، ط ب . . rم، دار قباء للنشر . 
ومن هذا الجانب علينا أن نغذي أولادنـا بالغذاء الطيب الحسل، والغذاء لا

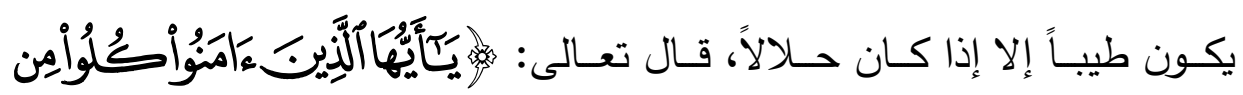

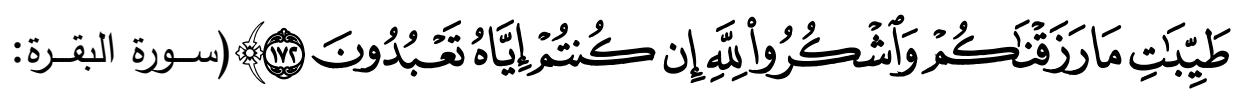
الآية (IVY)

ومن أسباب التربية السليمة الوقاية من الأمراض بالنظافة البدنية والبيئية قال

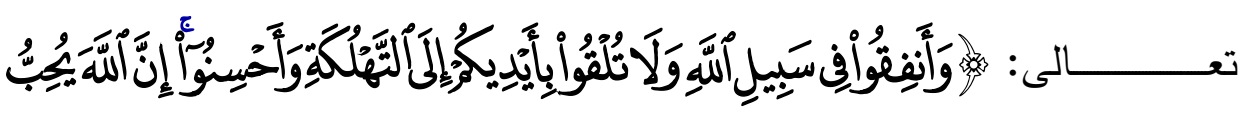

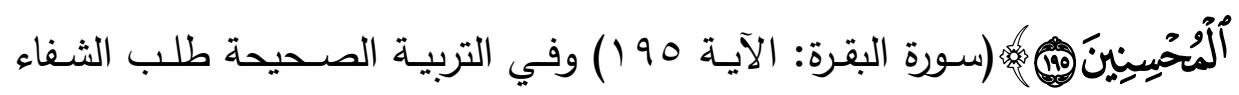

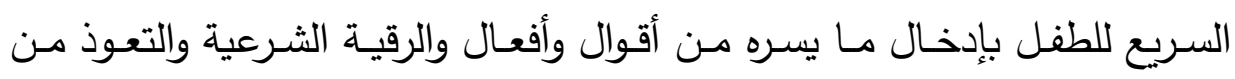

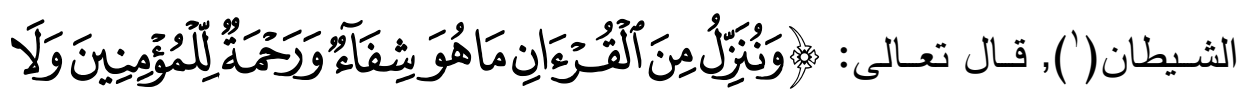

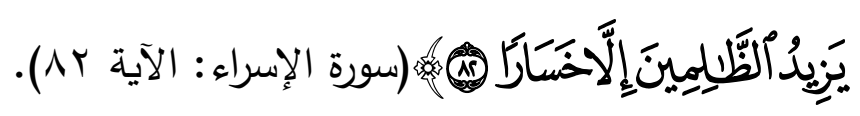
والتربية الجسمية والعقلية واجب اجتماعي، تغرس المحبة والنظام والتعاون

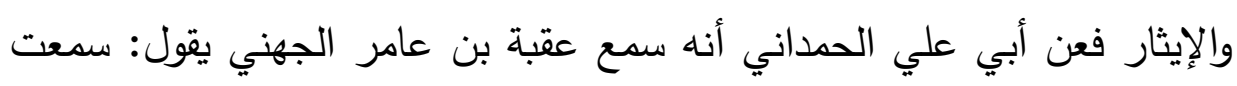

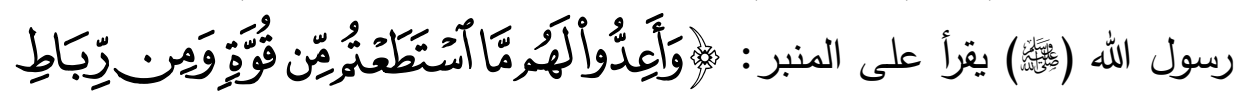

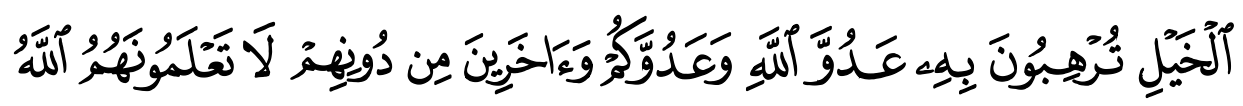

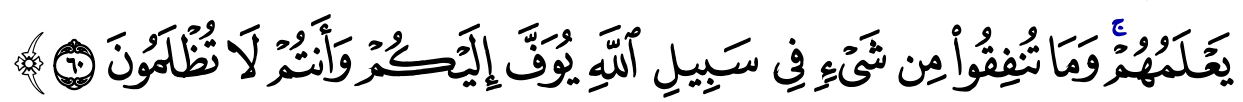

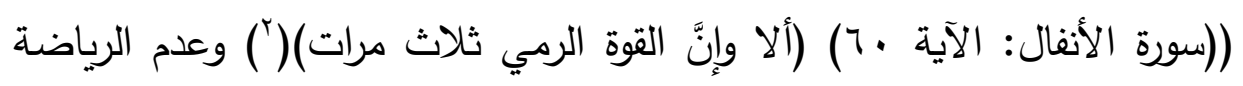

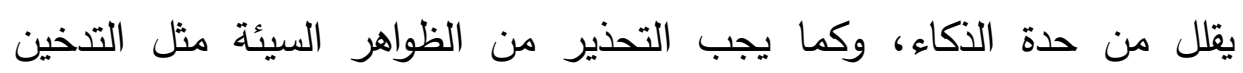
والمسكرات والزنا وغير ذلك.

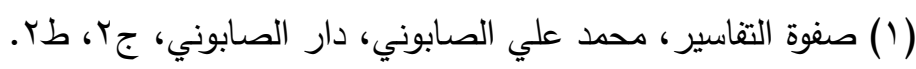

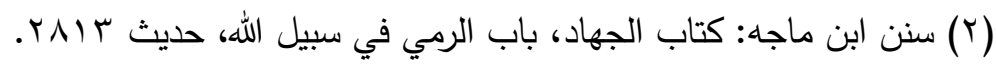
- Ir| - 
كما أن للعقل البشري طاقة من أكبر الطاقات على الإطلاق وهبها الله تعالى

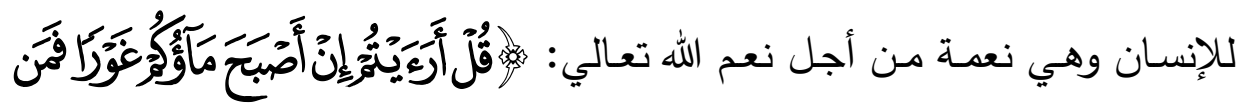

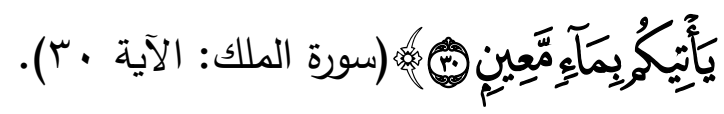
فالعقل ينمو مع تكييف البيئة الموجود فيها ويزداد تدريجياً نحو الأعلى على حسب تغذية المسلم والتي يمكن السيطرة عليها في الاتجاهات المعاكسة، لهذا بدأ الإسلام بتحديد مجال النظر العقلي وتصوير الطاقة العقلية وتبديد عوامل الفساد، ودعا إلي التفكر والتأمل في حكمة الله تعالى وتدبيره على إقامة الحياة على أساس

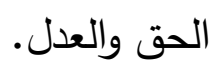
فتوجـه العقل لضـمان سير الأمسور على الأرض وأحوال الأمم والثـعوب على لـى

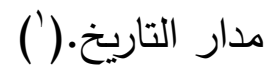
وهنا توجه العقل إلى استخلاص الطاقة المادية لتذليلها لخدمة الإنسان، وهذا هو الإسلام يحرص أشد الحرص على ربط القلب دائماً بالله تعالى ويوجه العقل إلى حكمـة الله تعـالى في خلقـه، فالعلاقـة دائمـاً مـا بين العبد وربهـ هي الإسـلام والإيمان والإسلام والأخلاق وخلافه وهي علاقة مودة وحب وتطلع ورجاء.

\section{Cत्र⿵冂人}

(1) انظـر التربيـة الإســلامية بـين الأصـالة والمعاصـرة، عبـد الغنـي النـووي، دار الفيحـاء 


\section{رابعاً: التربية الجنذماعية:}

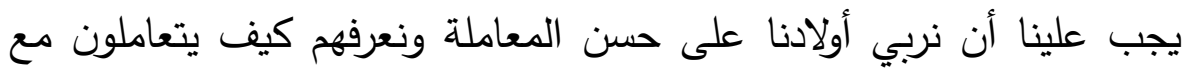

الناس بكل الطبقات وندعوهم إلى التواضع معهم، فعليهم احترام الكبير ورحمة تلفي

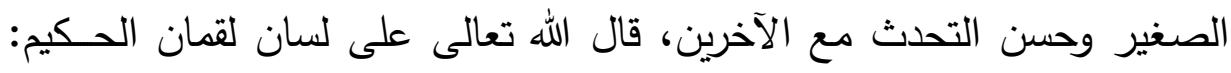

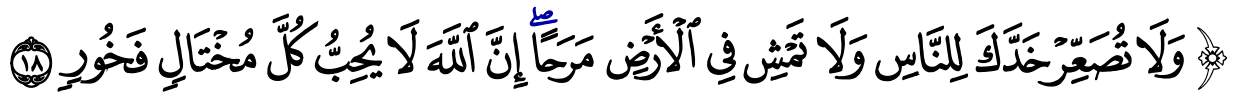

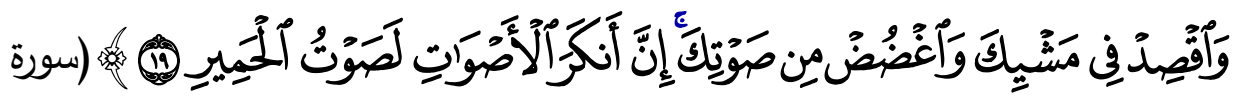

$$
\text { لقمان: الآيات 11 1 - (19). }
$$

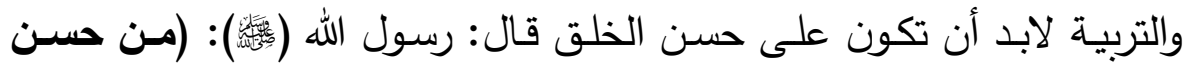

$$
\text { إسلام المرو تركه ما لا يعنيه)('). }
$$

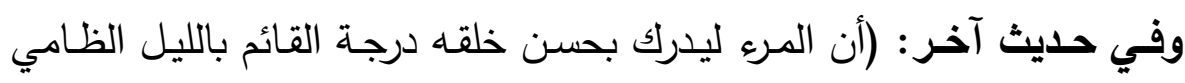

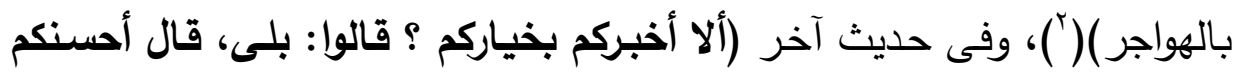

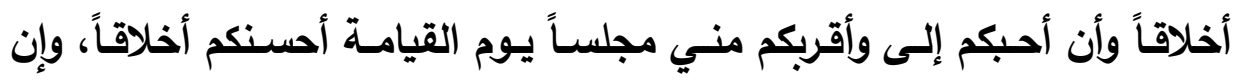

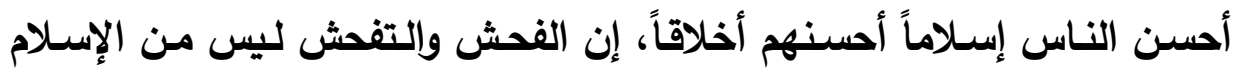

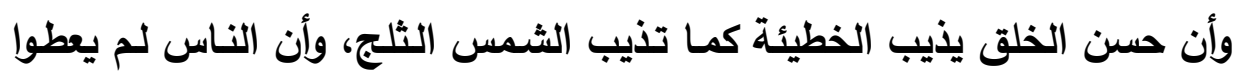
شيئاً خيراً من حسن الخلق)(").

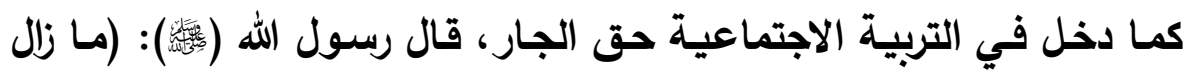

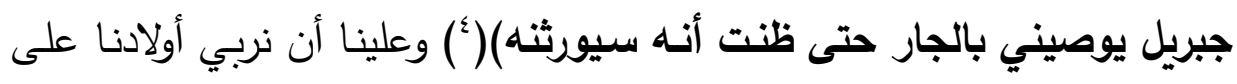

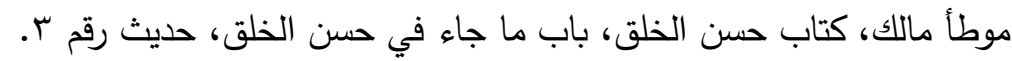

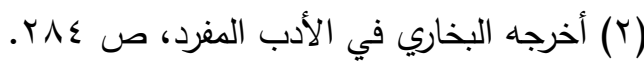

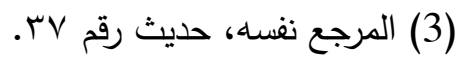

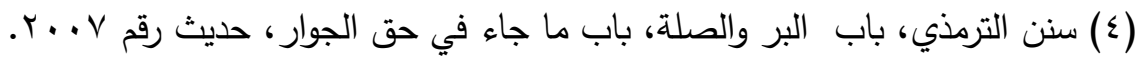
$-1 T H$ - 
عيادة المريض لما فيها من حسنات وتخفيف للألم وحق الجار وإكرام الضيف وغيرها، هذا من حقوق الإنسان لأخيه الإنسان كافراً أو مسلماً. ومن الأعمال الاجتماعية بر الوالدين لأن الوالدين من ضمن المجتمع من حول الأبناء، فالبر هو: لفظ جامع للخيرات كلها ويراد به التخلق بالأخلاق الحسنة مع الناس من حولك وبالإحسان إليهم وصلتهم والتصدق عليهم، وهو

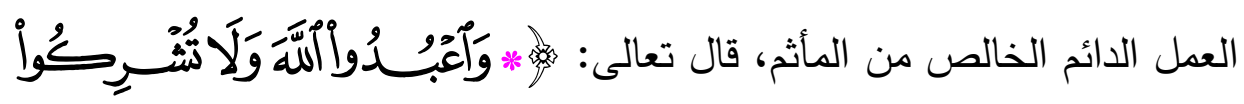

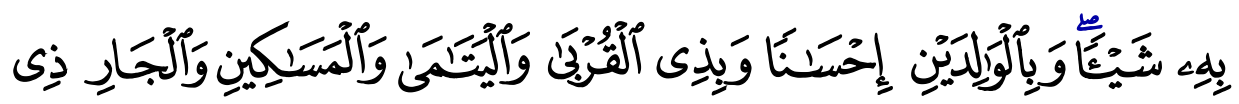

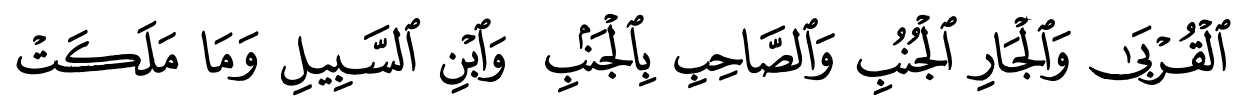

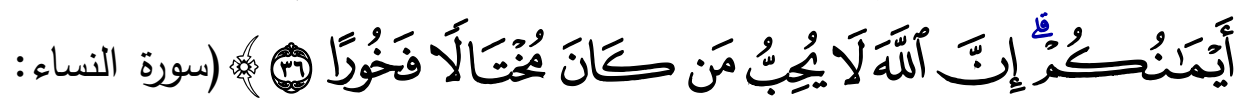

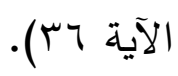
وقد جعل الله تعالى بر الوالدين والإحسان إليهما مستمراً حتى بعد وفاة الوالدين بالدعاء لهما بالرحمة جزاء ما ربيا وكفلا, قال تعالى:

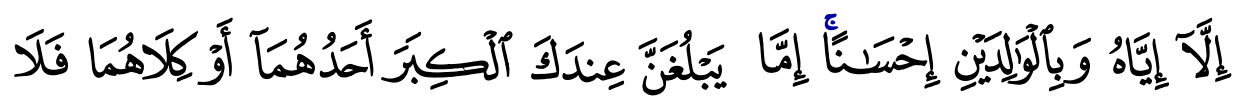

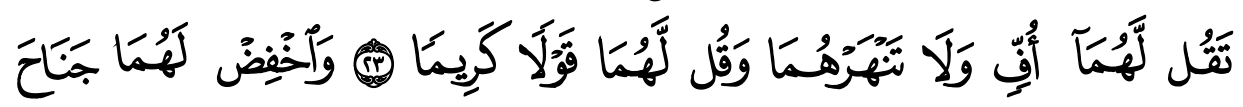

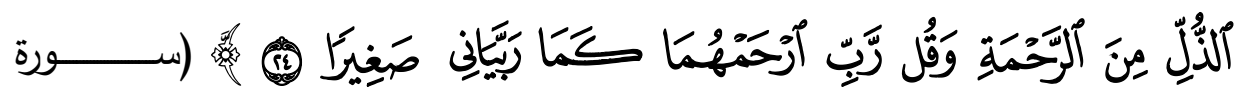

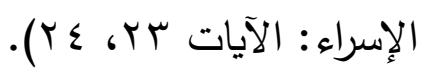

\section{Cत्र⿵冂人}




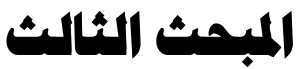

\section{ثماذه الثربية الدعوية للأبناء في القرآذ والهنة}

من الأصول التي قامت عليها تربية الإنسان في الإسدلام الفطرة السليمة التي تؤون بـالله تعـالى ربـاً وخالقاً، وتؤمن بالوحدانيـة لـه تعـالى وأنـه تعـالى قد خلق الإسلق

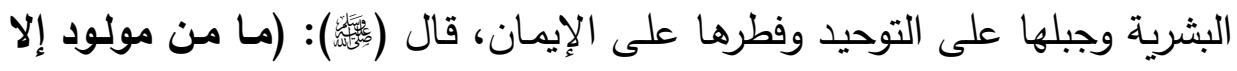
ويولا على الفطرة فأبواه يهودانه أو وينصرانه أو يمجسانه)(' ). فمن تلك التربية

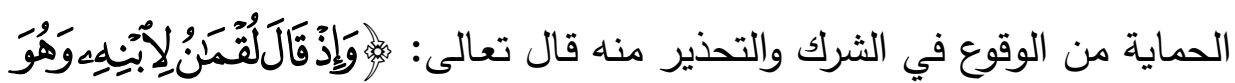

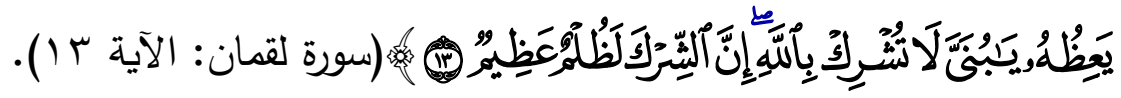
ووصية لقمان لابنه ركزت على الملامح العامة لتربية الطفل وتمثل في تربيته على الأمـر بالمعروف والنهي عن المنكر وإقامـة الصـلاة وعلى طاعـة الوالدين والتحذير مما يصيب الإنسان من العقوق وخطورة الشرك، فالأساليب التربويـة لهذا

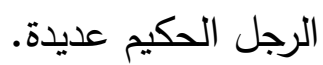

وقد بدأ لقمان الحكيم دعوته لابنه وهى للأبناء جميعاً بعدم الشرك بالله وأن الله واحد يستحق العبودية والشرك باله هو أسـاس الظلم ويتفرع منـه بقية أنواع الظلم والمظالم. والثـرك بـاله: هـو كـل عمـل أو قول أو اعتقــاد أمـر الله بـهـ أمـر إيجـاب أو استحباب فصرفه لغير الله, فالظلم أنواع ومستويات، فأي ظلم أكبر من هذا الظلم الذي يقع فيـه الإنسان حين ينحرف عن هذه الحقيقة الظـاهرة التي تقوم عليها السماوات والأرض، وأي ظلم أعظم من إنكار الحق الذي يستجير بـه الكون كله

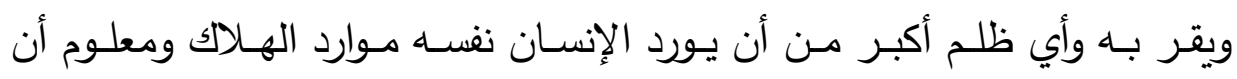




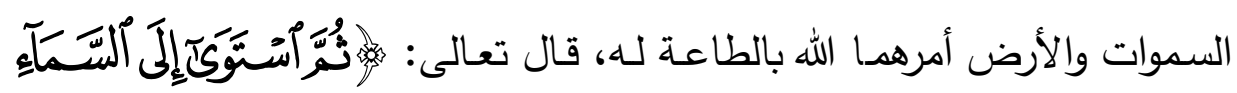

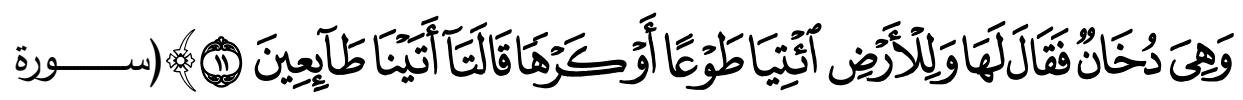
فصلت: الآية (1)(')('). ومن هذه الحقيقة يصف القرآن الشرك بأنه ظلم كبير عظيم، ويصف المشركين

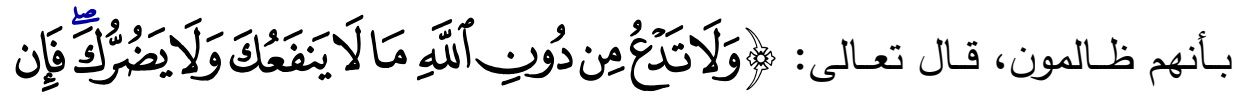

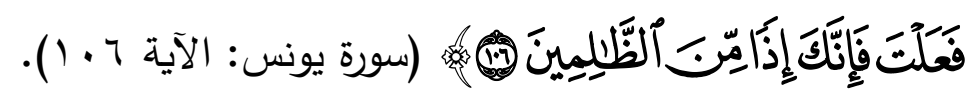
فالشرك انحراف عن المهمة التي خلق الجن والإنس من أجلها. وهى عبادة الله تعالى وتوحيده، والثرك يطفئ نور الفطرة، فالإنسان بابتعاده عن حقيقة التوحيد

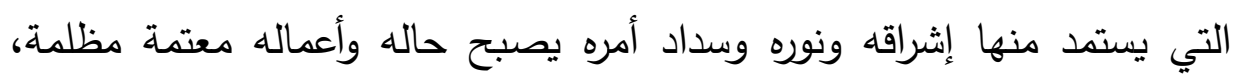
والشرك بالله يقضي على إشراقات النفس السامية المتعلقة بالله تعالى، والمتطلعة إلى رضاه بالابتعاد عن شهوات النفس ومتاع الدنيا على عزة النفس ويوقع صاحبه في العبودية الذليلة لأنه عبد لعبد وليس لله تعالى، والله هو العزيز بعزته وعظمته، قال تعالى:

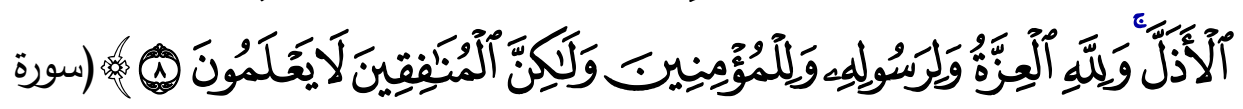
المنافقون: الآية ^)، ونربي أبنائنا على أن الثرك بالله يمزق النفس البشرية،

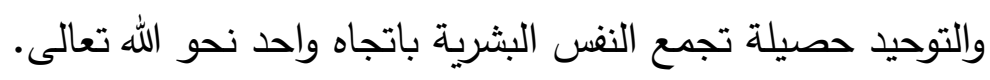
فالعقيدة هي أساس التربية الإسلامية والإيمان باله هو الموجه لسلوك الإنسان والدافع إلى اتجاه الخير والنصر لله من حيث الرعاية والتوفيق ويصرف الإنسان عن طريق الشر ويجعله متحلياً بالفضـائل وحسن الخلق وينظم عقيدته وتقكيره

(1) راجع مواجهة العولمة، زكريا بثير إمام، مركز قاسم للمعلومات والخدمات، طا . . بع. 
وأهدافه ويجعل لله عواطف وسلوكاً وعادات قويـة متعاونـة ترمي كلها إلى تحقيق هدف واحد وهو الخضوع إلى الله تعالى وحده والثعور بألوهيته وعظمته ورحمته ونها

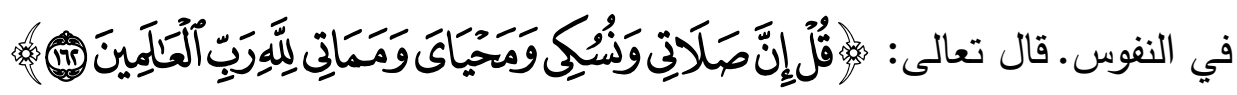
(سورة الأنعام: الآية باج ().).

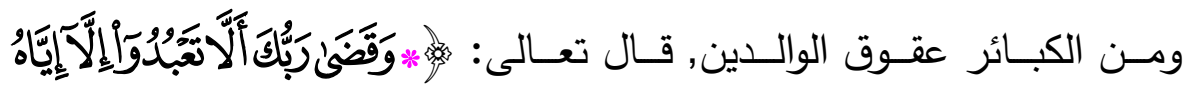

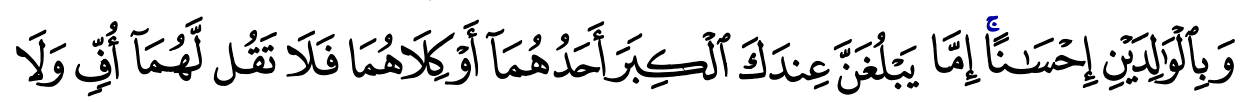

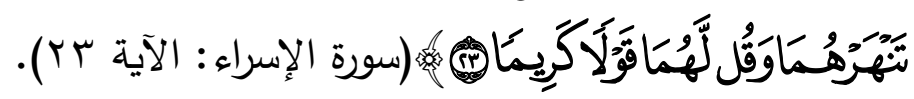
فبرهما وعطفهما واجب وصسى بـه الله تعالى وبالذات عند الكبر، لا تقل لهم

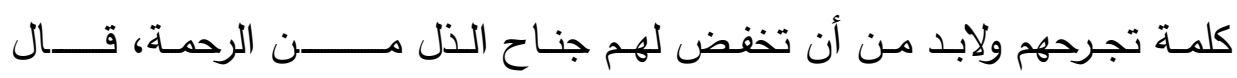

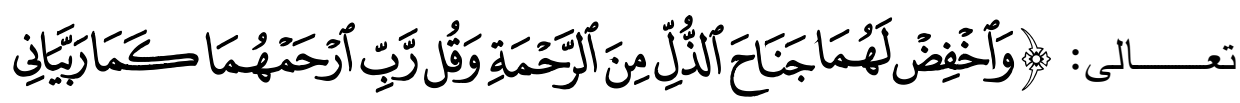

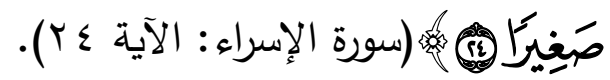
فعقوق الوالدين لـه مظاهر عديدة وصور شتى فمن الأبناء من يحزن والديـه سواء بالقول أو الفعل. فرفع الصوت والعبوس وتقطيب الجبين في وجه الوالدين وعدم البشاشة وعدم انتقاء الكلام الطيب وعذب الحديث في حضرتهما يجعلك عاقاً لهما. ثانياً: ركز لقمان الحكيم في تربيته لابنه على إقام الصـلاة والأمر بالمعروف

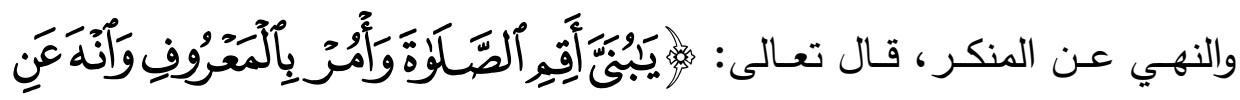

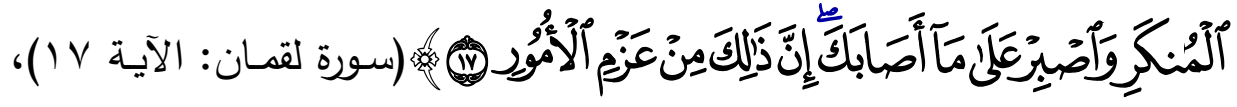
يعني الإسلام عناية خاصـة بتربية الروح وهي نقطة الأساس لصلة الإنسان بربـه وهي صلة دائمة في كل الأوقات. 
فالروح تبقى مشرقة لأنها متصـلة بخالقها، والصـلاة هي أولى الفرائض وبها منهج متكامل لتربية المجتمع وتطهيره ظاهراً وباطناً، وفي الصلاة ما يشد الإنسان من مساواة وعفة ومحبة ورحمة وقوة وأدب وواقع حي ملموس، هنا لا فضل لعربي على أعجمي إلا بالتقوى وفي إقامة الصلاة برهان على صدق الإيمان وعلى تقوى ولى ولى

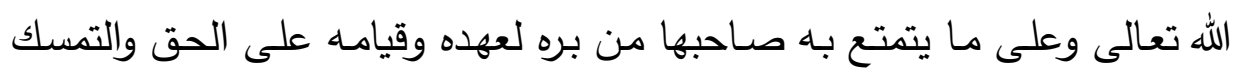

$$
\text { بالكتاب وتحمل مسؤولية الإصلاح('). }
$$

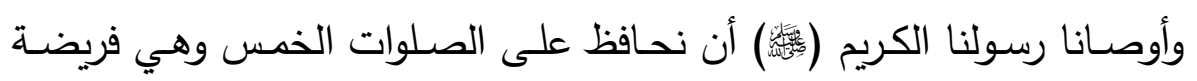
على كل مسلم عاقل بالغ, أما الصبي فعلى من يتولى تربيته أن يأمره بالصـلاة منذ سبع سنين وأن يضربهم عليها في سن العاشرة إذا لم يصلِ، ويجب على بلى ولي بريته الأمر الحرص على ذلك بأمر من الله تعالى في قوله:

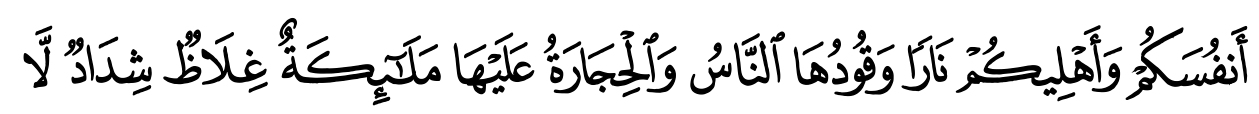

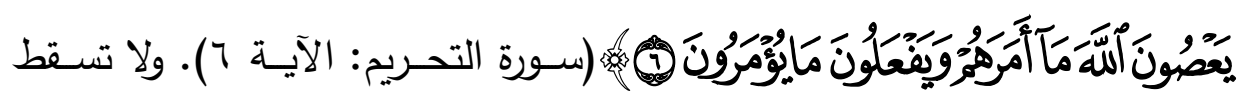
الصلاة إلا عن مجنون فقد عقله، فنربيهم على عدم ترك الصـلاة وأن تاركيها هم

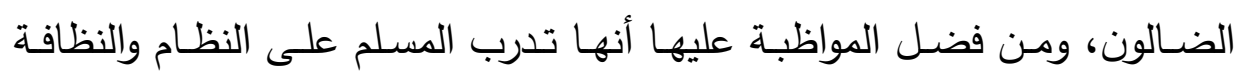
والتعرض لنفحات ربه. وكما شرعت الصـلاة في أول الإسـلام لتكون زاد المؤمنين وقوة الموقنين ودواء المتعسين والمضطهدين وسلوى الضعفاء ورحمة لكل من آمن برب العالمين، قال تعالى :

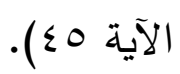

(1) فلسفة التربية الإسـلامية في القرآن الكريم، علي خليل أبو عينين، مكتبـة إبراهيم علي، إلين

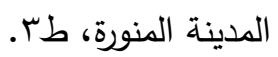


وشرعت أيضاً لتطهير القلوب من وستخ الجاهلية وقذرها وتطهير النفوس من أمراضها، وتخليص الأرواح من ظلماتها.

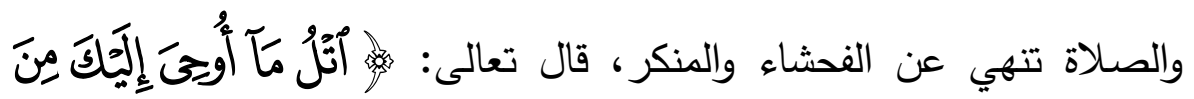

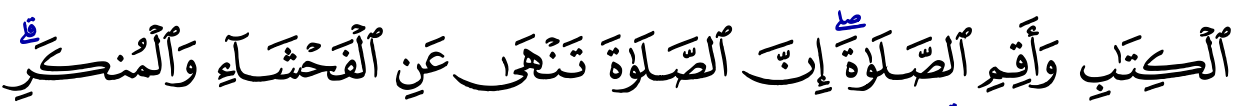

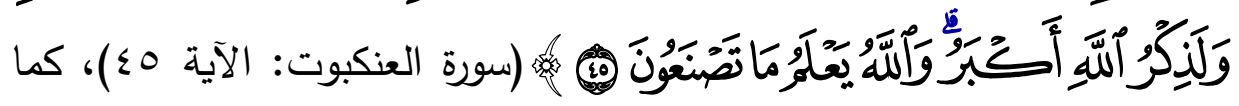
اختص الله تعالى الأمة الإسلامية بأن جعلها شاهدة يوم القيامة على جميع الأمم من قبلها لما تحمله من عبء الأمر بالمعروف والنهي عن المنكر وتلك مسؤولية

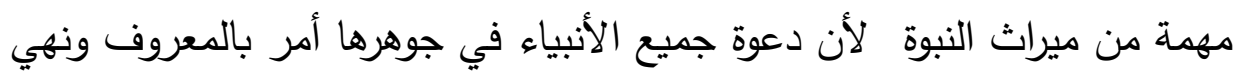
عن المنكر

ولا يتصور حال الأفراد والجماعات بدون الأمر والنهي ولا يستقيم حال أمة من الأمم إذا لم يكن لديها ما تأمر به وما تتهى عنه.

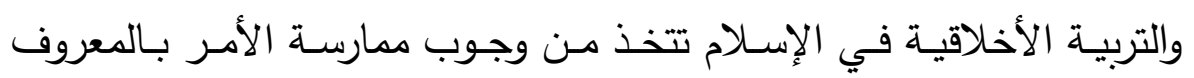
والنهي عن المنكر لدى المؤهلين له ركيزة تقوم عليها ولا تستغني عنها بأي حال،

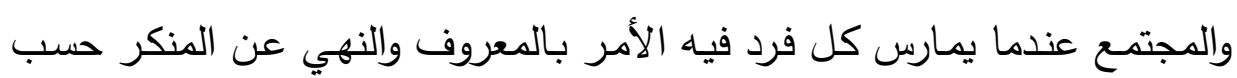
استطاعته واختصاصـه فإن الأخـلاق الفاضلة والخير والبر سوف يسود المجتمع فرع كله.

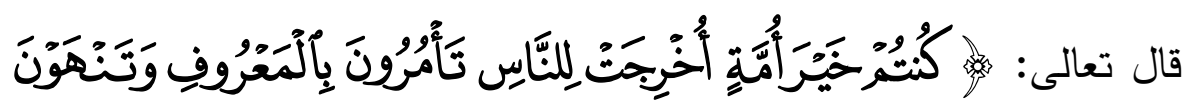

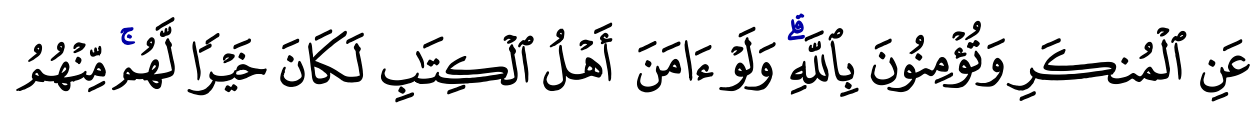

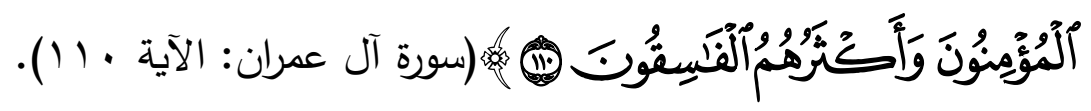
ومن الوصايا أيضاً: (لا تصعر خدك للناس ولا تمش في الأرض مرحاً) ويعني بها عدم الكبرياء والغرور وأن تعتدل في مشيتك وتخفض صوتك ولا تمش -119 - 


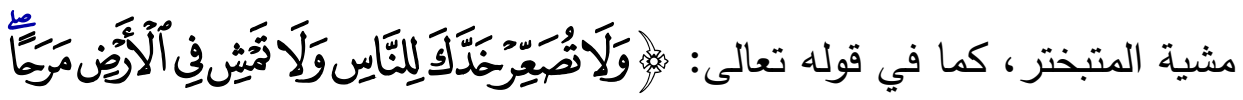

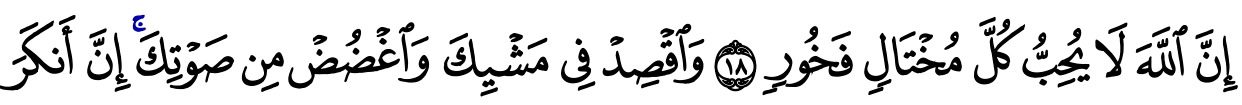

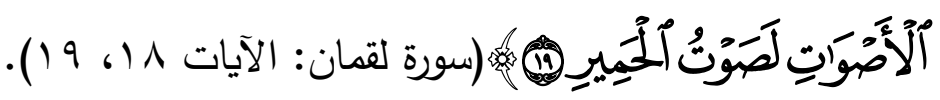
ومن النماذج القرآنية وصية إبراهيم ويعقوب ("تئيخ) لأبنائهم:

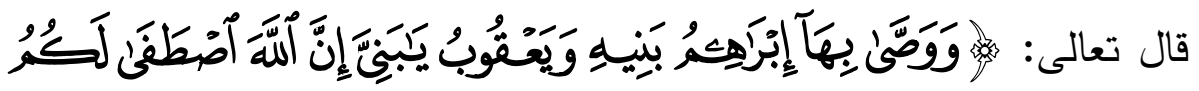

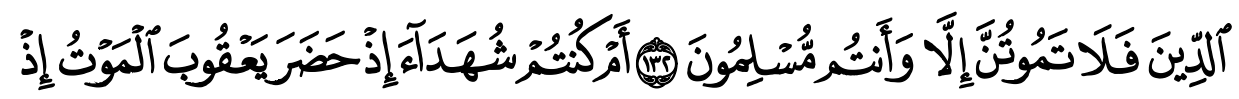

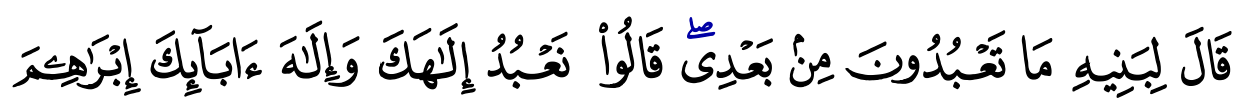

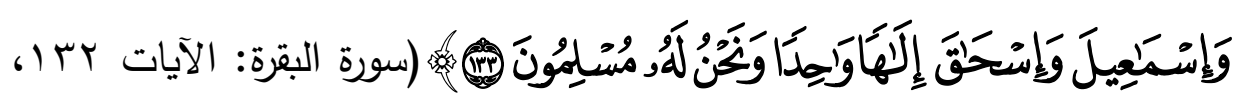
(1) قال تعالى في هاتين الآيتين أي وصاه على الملة، وهي الإسلام لله تعالى:

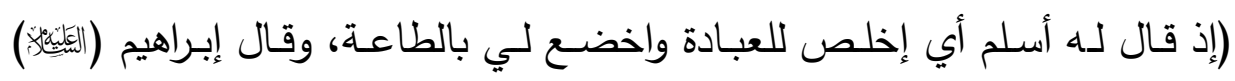

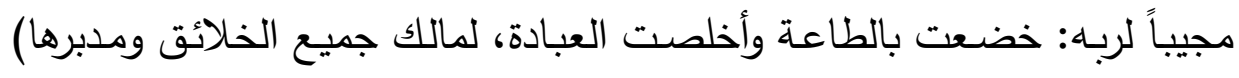

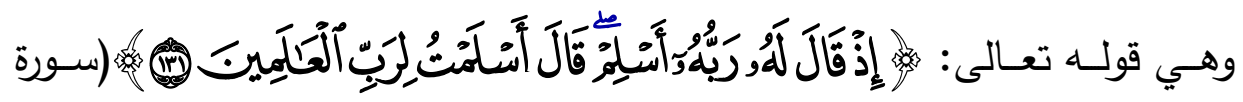

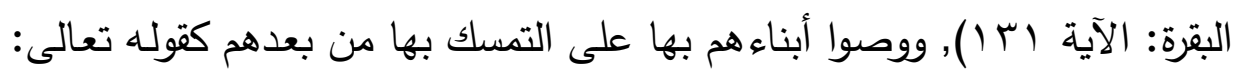

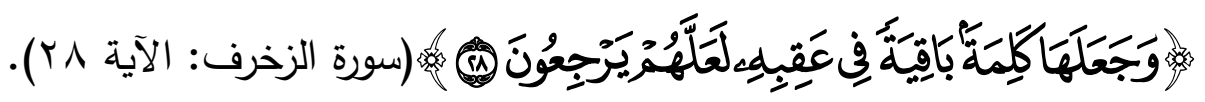

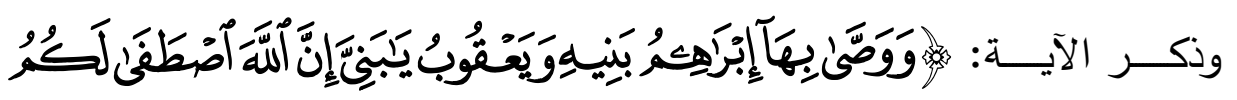

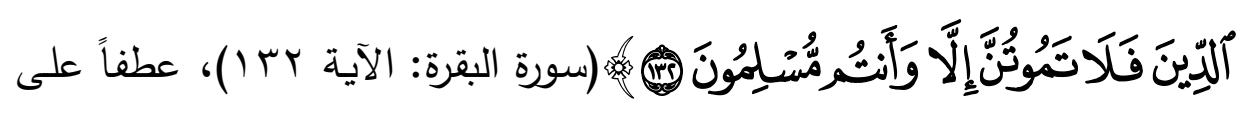

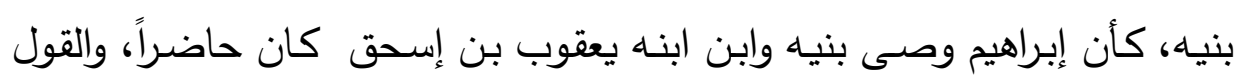

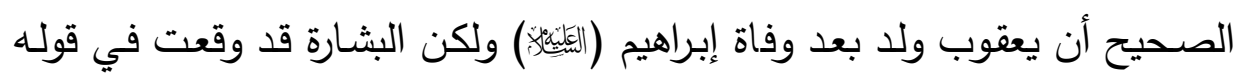


تعـالى :

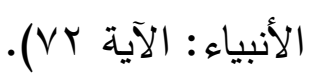

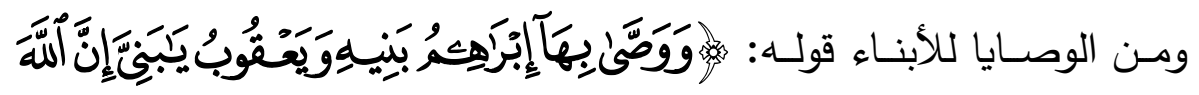

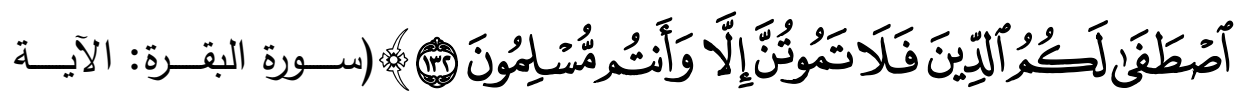
ץ T (), وهذه الآية تحث المسلم على الحياة الطيبة والعمل بمقتضى الدين، أما في قوله تعالى في وصية يعقوب لأبنائه وصـاهم بعبادة الله وحده لا شريك لله، فقال لهج: \}ما تعبدون من بعدي قالوا نعبد إلهك وإله أباءك إبراهيم وإسحاقئ وهذا من

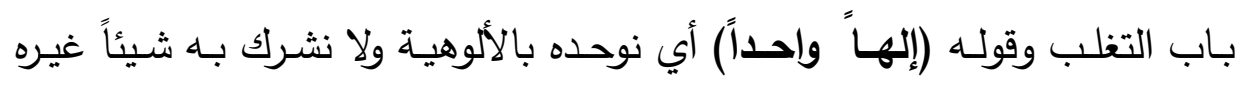
(ونحن لله مسلمون) أي مطيعون خاضعون، والإسلام هو ملة الأنبياء قاطبة وإن

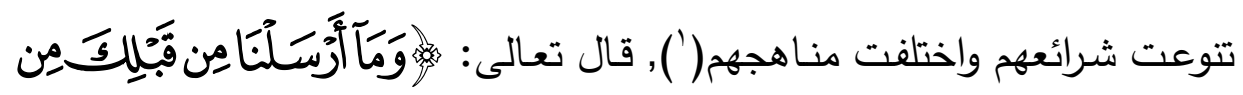

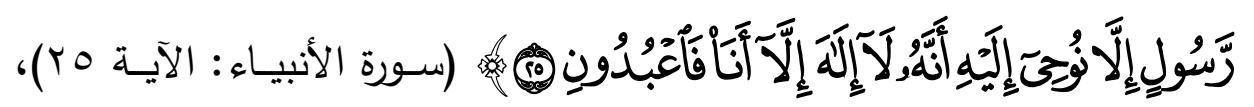

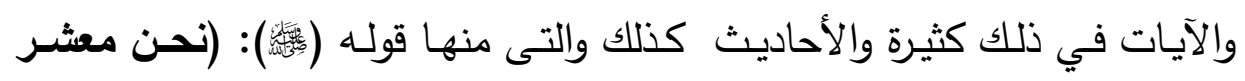

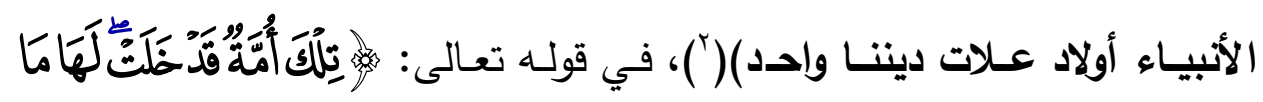

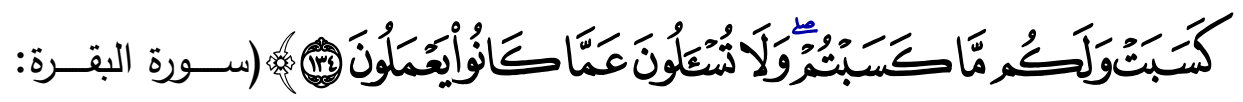
الآيـة ع ب ()، وهذه نمـاذج قرآنيـة من الأنبياء والمرسلين في تعليم أبنائهم قواعد الدين وتربيتهم على الأسس الصحيحة والتمسك بها في كل خطوة في حياتهم، ونسأل الله تعالى أن يكون أبناؤنا ممن يسمعون القول ويتبعون أحسنه.

(1) تفسير القرآن الكريم، ابن كثير المتوفي \&VVهـ دار المعرفة بيروت لبنان.

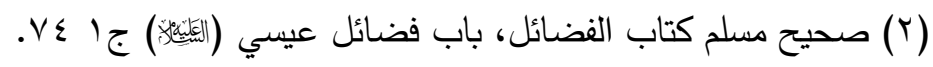


والسؤال عن الوصـايا هل هي تربية في أصلها أم هي وسيلة للوصسول إلى

التربية؟

خلاصة القول: أن الوصايا أصول دينية مفطور عليها الإنسان في الأزل قال

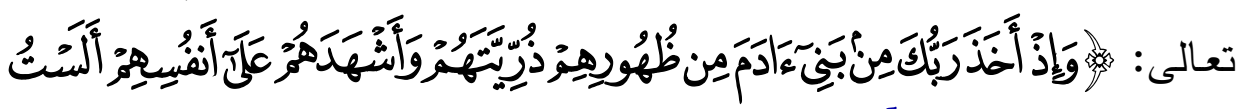

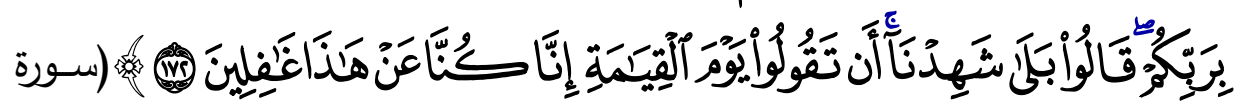
الأعـراف: الآيـة V V ( )، وفطـرة الإنسـان لا تخـرج مـن أركـان الإسـلام وأركـان

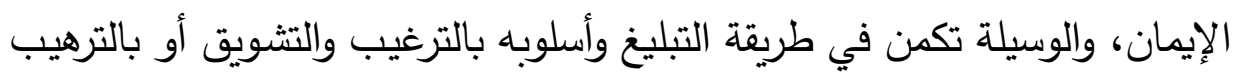
من غضب الله (كَّكَلْ) عند عدم العمل بما جاء بـه الشرع.

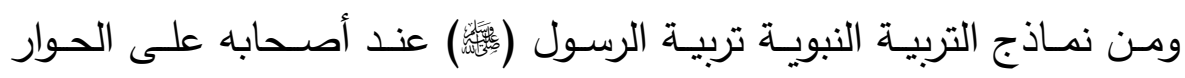

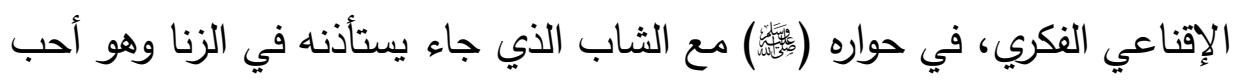

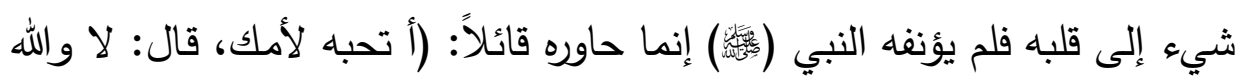
جعلني فداك قال: ولا الناس يحبونـه لأمهاتهم، قال أتحبـه لابنتك قال لا: والله يا

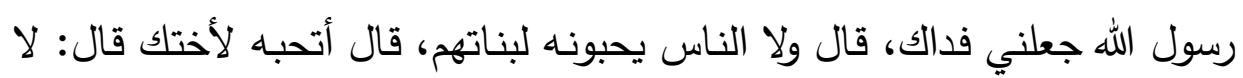

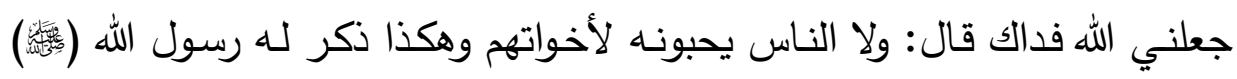

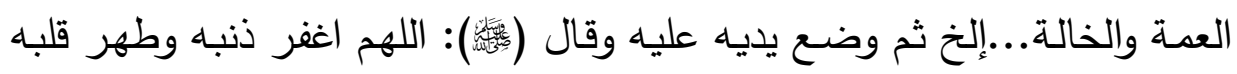
وحصن فرجـه)('). فكان في بدايـة الأمر محبباً إليه ثم أصبح ولم يكن شيء

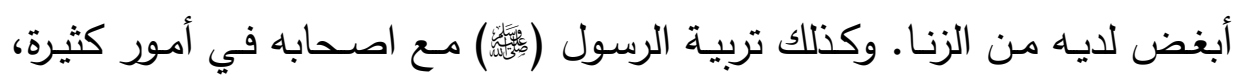

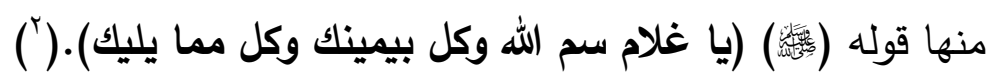
والمواعظ كثيرة في القرآن الكريم أمسا الملاحظة في هذه الآية والآيات القرآنية الأخرى أنها صدرت من كبار المصلحين وهم الأنبياء والمرسلون، كما ظهرت هذه 
وصية لقمان لابنه ووصية يعقوب لأبنائه, وهي طريقة عظيمة من طرق التربية

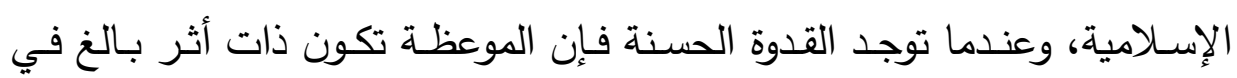
النفس وتصبح الدافع في تربية النفس والمواعظ القرآنية تعدّ أسلوباً تربوياً رائعاً

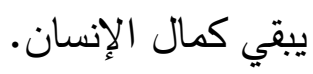
لذا فإننا نجد أن معظم المواعظ القرآنية تدور حول تربية الإنسان تربية عقائدية وسلوكية لتكوين وتتشئة وإعداد المسلم الصالح.

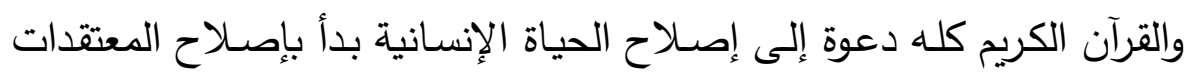

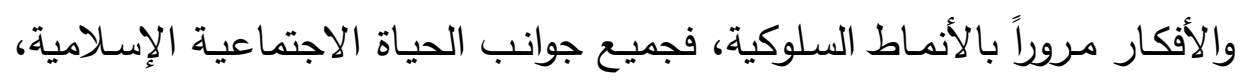

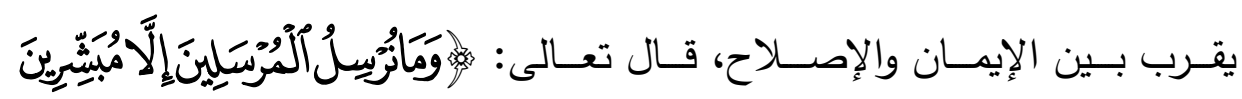

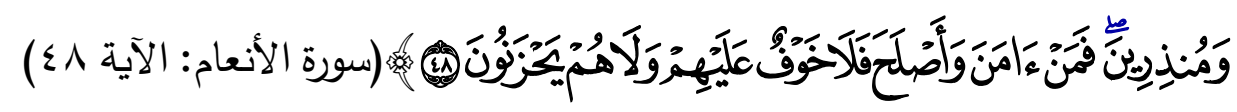

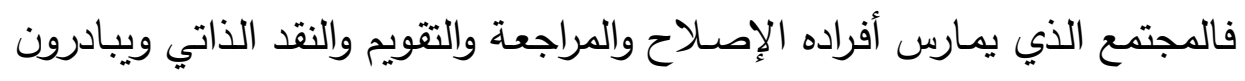

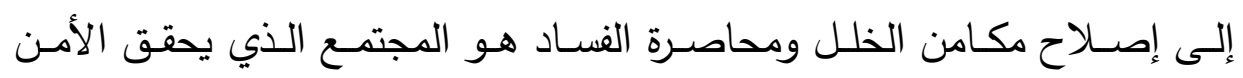

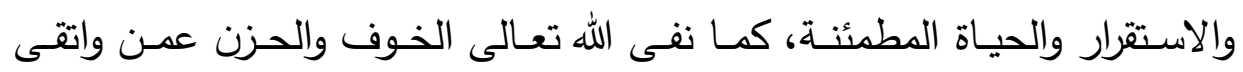

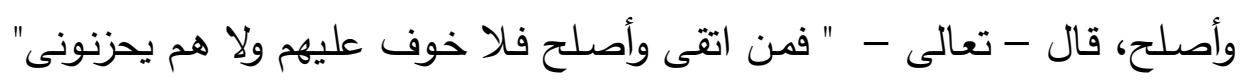

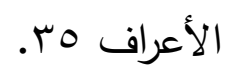

\section{(}




\section{البمش البمابه}

\section{تمديات الثزبية الاماهرة وطدق معالمتها دوميكا}

في البدء نتحدث قليلاً عن أهمية الأم والأب في التربية بالنسبة للطفل الصغير خاصـة والأبنـاء عامـة فمعلوم أنـه لا يستطيع الرجل أن يســ مكان الأم ودورهـا والعكس كذلك في التربية وليس دور الأم فقط تأمين الغذاء للولد ورعايته بدنياً بل لـ لرج دورها الأكبر والأعظم هو ذلك الحب المتدفق من قلبها على الولا والحنان الذي لـي يثعر به الولد، وأهم مظاهر ذلك الحنان الذي يشعر فيه الولد بالأمن والسعادة

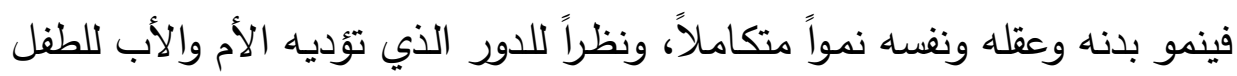

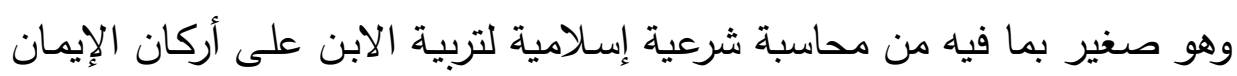

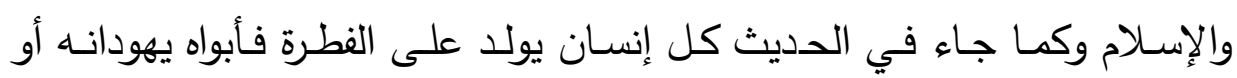
يمجسانه أو ينصـرانه، فعلى الآباء والأمهات رعايـة الأبناء على أتم وجـه لأنهاء مسؤولون أمسام الله تعالى قوا أنفسكم وأهليكم نـاراً فالتربية السليمة من أهم دعائم الأسرة المسلمة ومن أعظم أسباب استقراها النفسي والاجتماعي ولكن إذا فقد الابن أحد الأبوين أو الاثثين معاً سـواء كان بـالطلاق أو بعدم استقرارهما في الجـو الأسري فهذا يؤدي إلى الانحلال والانحراف(').

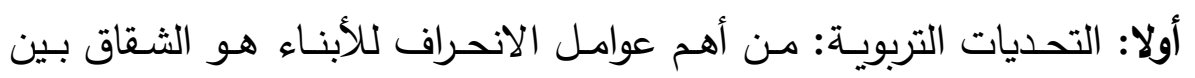
الزوجين، فالثقاق يؤثر على نفسية الأطفال مما يؤدي إلى انحرافهر عن الأسرة وعن المجتمع واستمرار الثقاق ما بين الأب والأم في أعظم الأوقات, فالولد حين ينشأ ويرى

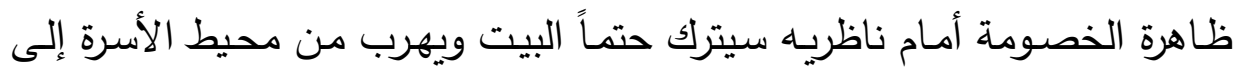


رفاق الثوارع وما أدراك ما الثارع ! فسيتدرج معهم على الانحراف ويتدنى معهم ألما

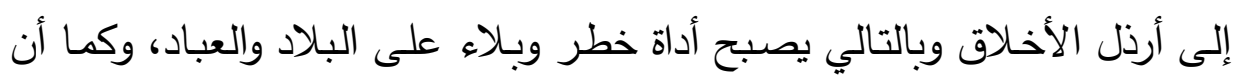

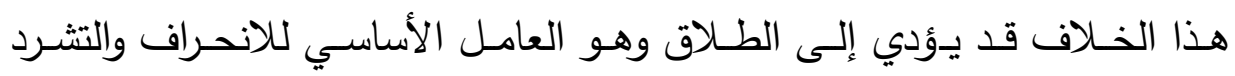
والضياع. ثانيا: الخلل من الأبوين أو أحدهما عندما يقصر في التربية أو ترك التربية

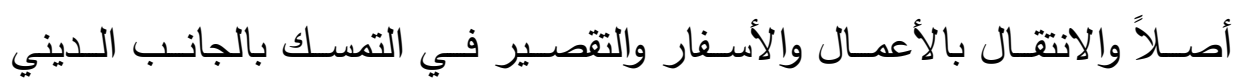

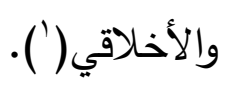

ثالثاً: اليتم، الولد إذا مات أبوه يفقد الأسوة والقدوة ومعها تسوء تربية أخلاقه، وربمـا فسـدت معيثـته ولقـد حث الإســام على رعايـة الأيتـام وكفـالتهم الماديـة والمعنوية والتربوية والأخلاقية والاجتماعية والعاطفية. رابعاً: الصحبة السيئة من أسباب الانحراف، فكثير من المنحرفين يرجع سوء والهائه واهيه

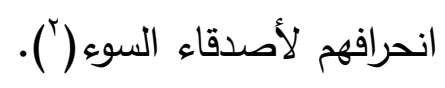

خامساً: الفقر ، وله دور مهم في علوم تربية الطفل تربية حسنة، فالطفل إذا لم يتوفر لله متطلبات الحياة من غذاء وكساء وغيره وينظر إلى ما هو حوله فيجد الفقر والحرمان ومن المؤكد يرجع إلى الخارج للبحث وراء الرزق، فتلتقطه أيدي السوء فيعيش في المجتمع مجرماً خطرا على الأنفس والأموال. والإسـلام قد حدد السى للفقراء الإعطاء من بيت المال لكل عاجز ومعوز .

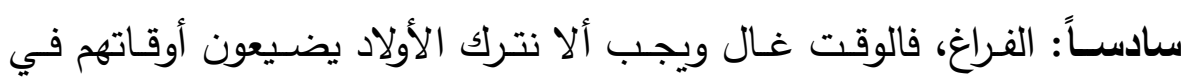

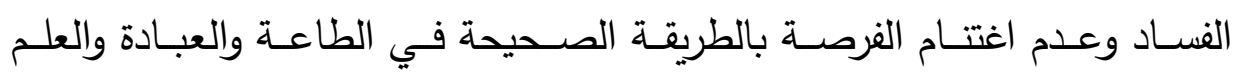
والمحافظة على الأذكار والانتقاع بالطاعات.

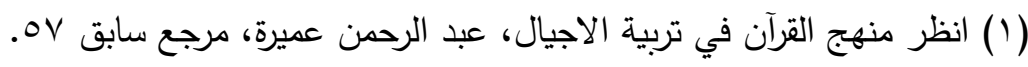
(Y) انظر تربية الطفل من القران والسنة، سيد احمد جمعة، مرجع سابق. 
سابعاً: من أهم عوامل الانحراف العولمة والغزو الفكري عبر الوسائل المرئية والمسموعة, والتى لها إيجابيات وسلبيات على الجيل الحاضر وتطرق هذا البحث على الجانب السلبي فقط لأنـه يعد إحدى التحديات. وغفلـة الوالدين والمـراقبين لتربية الطفل من خطورة الموقف وتمسكهم بالجانب الإيجابي فقط. فهو من أهم أسباب الانحراف على الجيل المعاصر وهي، التي تتسرب لعقول المسلمين لتغيير المفاهيم والثقافات والعادات والتقاليد والحضارات وصبغ الأفكار بمفهوم غربي('). والعولمـة تعنـي الاستلاب الثقافي وتدمير الهويـة الوطنيـة وهي خدعـة كبيرة ومـؤامرة عظمى للسـيطرة الثـاملة الكاملـة على العـالم لـيس فقط في الجوانـب السياسية والاقتصادية والعسكرية, بل حتى في مجال الثقافة والقيم والأخلاق. ومفهوم العولمـة بشكل عـام هـو انـدماج السـوق العالميـة في حقول التجـارة والاسـتمار المباشـر وانتقال الأمـوال والقوى العاملـة والثتقافـات ضــن إطـار مـن الرأسمالية وحريـة الأسـواق العالميـة ممـا يؤدي إلى اختـراق الحدود القوميـة وإلى لى الانحسار الكبير في سيادة الدولة. إذن العولمة تعني إزالة الحواجز بين الثقافات والانفتاح عالمياً ليصبح العالم

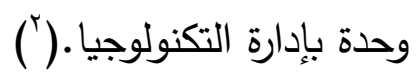

والعولمـة هي دمـار للحضـارة والثقافة الإسـلامية وانتهاك حقوق الهويـة القومية وتحطيم الحدود الإنسـانية في التعامل مـع الحياة، وبالأصـح هي استيطان يقوم

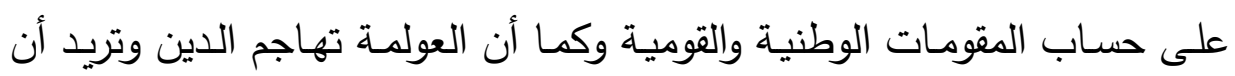

(1) العولمـة قدر ام اختيار، الطيب علي عبد الرحمن، وزارة الثقافة والسياسـة، طا ؟ ...rم الخرطوم.

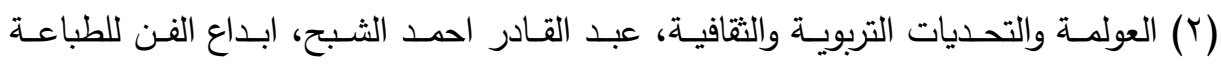
ـ 
تجعل العـالم لا ديـن لـه وتنقل فكر النـاس بالـنيا ونعيمها الزائف عـن الآخرة ونعيمها الدائم.

ومما شكل خطورة علينا نحن المسلمين وقد لا نعيره اهتماماً أن الغرب يقوم

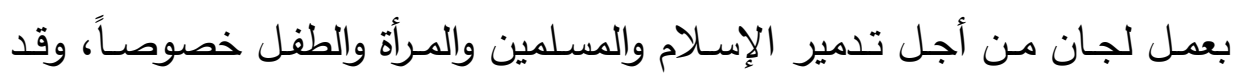
أكدت لجنـة سيداو مـراراً أنـه إذا تصـادمت آراؤهـا حـول حقوق المـرأة مـع الـدين والثقافة، فعلى الدين والثقافة التتحي عن الطريق، بل طالبت اللجنة علنـاً بإعادة

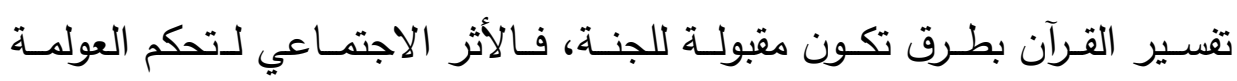
بالشعوب في أدائها واضح، فأصبحنا نتبع الغرب حتى في مجتمعهم وبيئتهم التي

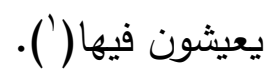

ومن الآثار الاجتماعية التي خلفتها العولمـة أنشطة شركات المافيا في نشر المخدرات بأنواعها في البلدان العربية لتحطيم شباب الأمة وجعلها أمة عليلة خاملة ونجحت في ذلك، فاليوم قد أصبح الكثير من الثباب في أعمار صـيرة جداً يعانون من الإدمان.

وانتشار الجمعيات الفعالة المنحرفة في البلاد مثل جماعة عبدة الثيطان وهي

مؤامرة صهيونية(').

ومن الآثار الاجتماعية الخطيرة التي خلفها الاستعمار بعد الأثر الديني انهيار المبـادئ والقـيم الأخلاقيـة، وقـد أدت العولمـة إلىى التخلـي عـن المبـادئ والقـيم الأخلاقية الدينية والقومية الأصيلة من أجل الحصول على منافع مادية بدون وجه الاحهـ حق، وحتى تصبح أنواع الفسـاد المختلفة مهارة أو نشاطاً بينمـا أصبح الاجتهاد الاديه

(1) العولمة والجدال الدائر حولها، فلاح كاظم المحسن، طا، ؟ ... rم، دار الوراق للطباعة والنشر

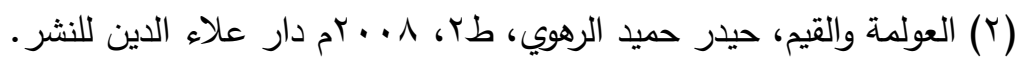


والتمسك بالدين والقيم الأخلاقية السليمة في عرف هؤلاء تخلفاً أو جموداً في الفكر عكس مضــمونها الحقيقـي، وازدادت الخطـورة عنـدما شـب العديـد مـن الـنشء والثـباب على هـذه القيم والأفكـار المخلوطـة والمغلوطـة مدـا يـؤدي إلى عـدم الاهتمام بالعمل والعلم والتعلم والاجتهاد كوسيلة للكسب والحصول على الدخول، فيؤدي إلى شيوع قيم الفساد حيث يسود السلوك المنحرف. ثامناً: الغزو الفكري: أمـا الغزو الفكري فهو لا يختلف كثيراً عن العولمة لأنه

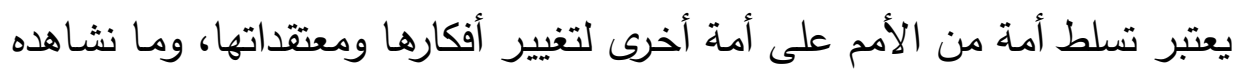
اليوم في العالم النامي من صـراعات سياسية وعسكرية، مـا هو إلا نتيجة الغزو الفكري الثقافي الذي استطاع أن يفرق بين أبناء الوطن الواحد، لكي تعيش وتظل شعوبنا نامية وضعيفة وخاضعة لنفوذ القوة المسيطرة، فالغزو الفكري يحول بين الأمسة وتاريخها وتراثها وماضيها وثقافتها،وهن أهم مظاهرهـا الفسـاد الاجتمـاعي وهي من فلك الروابط الاجتماعية المتمثلة في الأسرة والدولة والانفراد في الفكر والسلوك الك والانتماء والقبلية والفساد الأخلاقي والسلوكي والرذيلة، والفراغ والملل متمثلة في ما يعرف بغسل الدماغ ومله الفراغ بالمعتقدات الفكريـة المسمومة وهدم مقومـات الأمة وعقائدها ودس الأفكار الفاسدة، وإغراء الجهلة وإثارة الشبهات والجدل حول القرآن والسنة والتشريع بالفلسفات الهدامة. (')

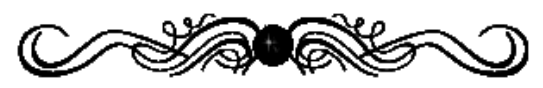

(1) الغزو الفكري العولمـة، تحديات التربويـة والثقافة، عبد القـادر احمد شبح مرجـع سـابق 


\section{طرق| لمعالجانه:}

• من أهم المعالجـات: العمل بالقواعد الأساسية للتربية التي تعرضنا إليها في المبحث الثاني.

القدوة الحسنة في قوله تعالى :

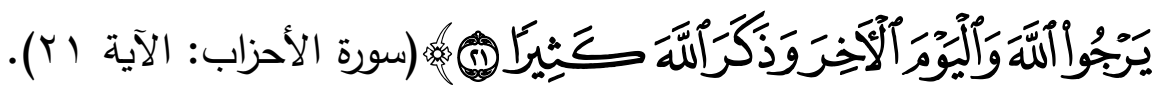

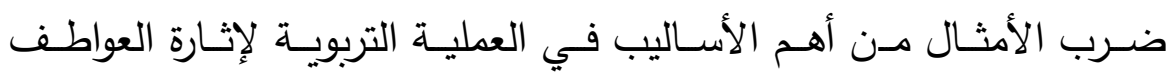

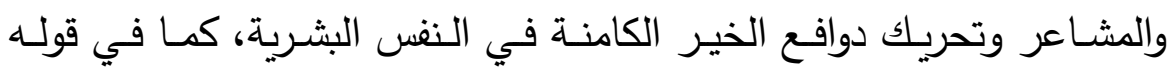

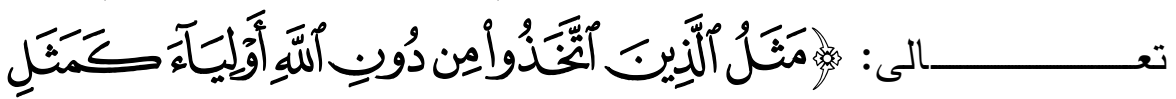

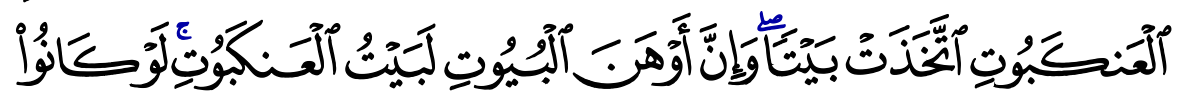

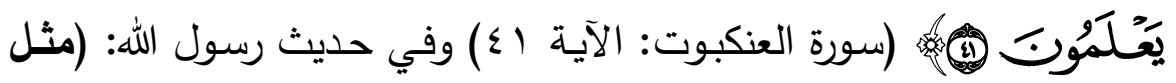
المؤمنين في توادهم وتراحمهم وتعاطفهم كمثل الجسد الواحد إذا اشتكى منه عضو تداعى له سائر الجسد بالسهر والحمى) (').

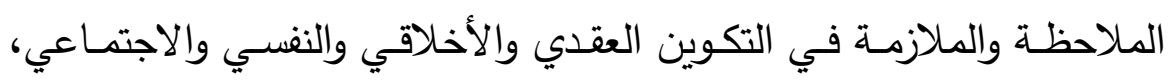

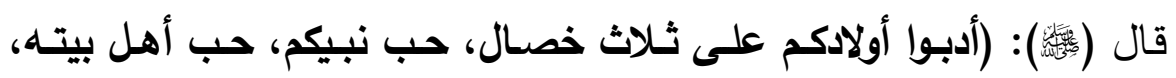
وقراءة القرآن)( (ال). الحوار والإقناع الفكري والاستجواب من الأساليب المهمة في ترسيخ العقيدة

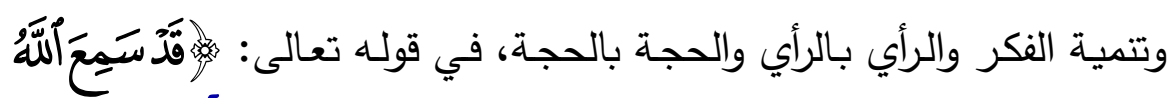

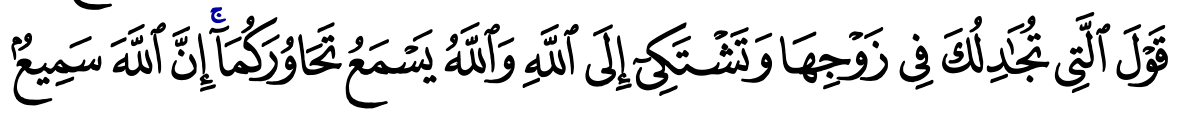

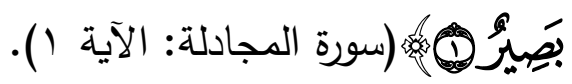

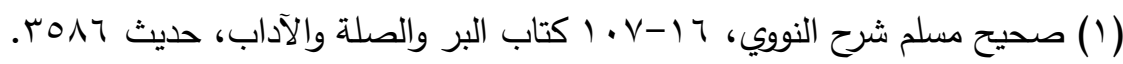

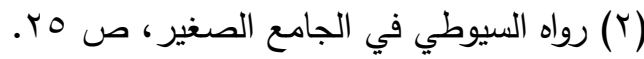


الموعظـة وهي مـن أهم الوسـائل المؤثرة في التربيـة الإيمانيـة وإعداده خلقياً

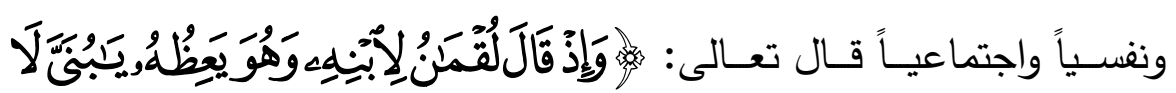

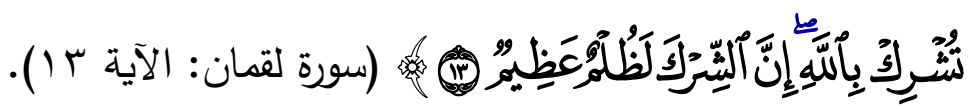
القصسة أسلوب تربوي جذاب من أسـاليب التلقين دوره في ترسيخ القيم الدينية

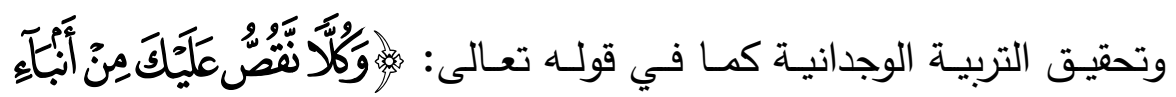

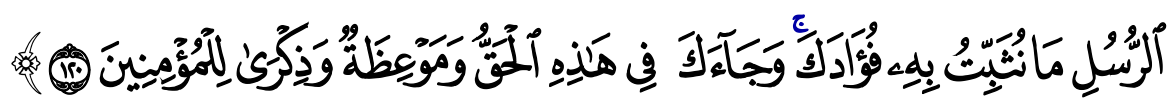

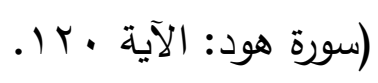

التربيـة بالأحـداث وهـي أحـاث تقـع على المـرو بسـبب تصـرفاته الخاصــة الخارجة عن تقدير إراداته ومنها أمثال كثيرة كحادثة الإفك، والظهار ووانهزام

$$
\text { المسلمين يوم حنين...إلخ. }
$$

الترهيب والترغيب من الأسـاليب الناجحة لتربية النشء بـل حتى الكبار قال

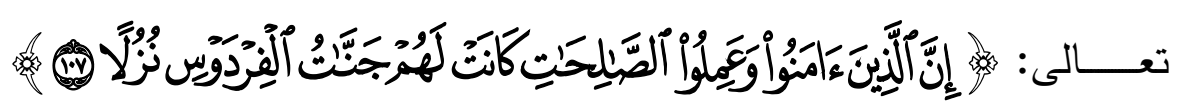

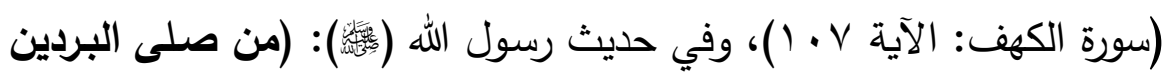

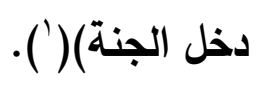

ومع هذه الأساليب على الآباء والمربين كافة أن يفهموا حقيقة القرآن الكريم والسنة المطهرة كمناهج أساسية في إعداد الصغار قبل سن التمييز وبعدها إيماناً وخلقاً وتكوينهم نفسياً واجتماعياً لكي يصلوا إلى النضج الحقيقي والعقل المتزن لمواجهة التحديات المعاصرة لأبناء الأمة الاسلامية.

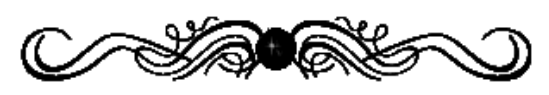

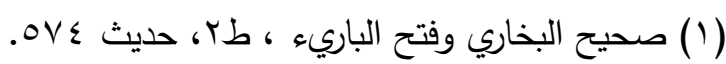




\section{|لننائج والنوصيانه}

|لننائج:-

• مسؤولية المرأة المسلمة كبيرة نحو بناء جيل واعد ينطق بالحق ويتحمل مسؤولية الأمة المسلمة.

• المحبة في الاحترام المتبادل بين الزوجين لها دور مهم في تماسك الأسرة وتربية جيل صحيح معافى من الانحراف وأنواعه.

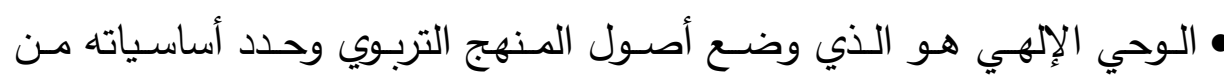

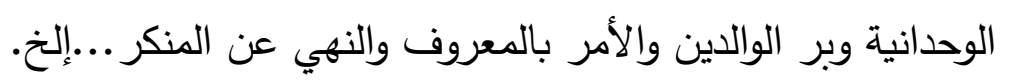

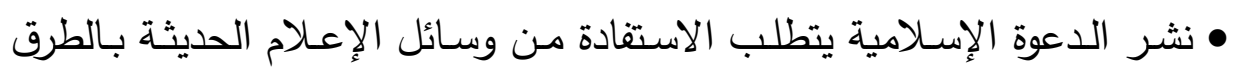
الصحيحة لكي تؤثر في تربية الجيل الإسلامي المعافى.

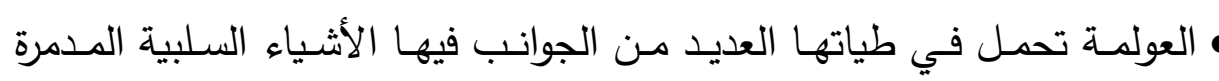

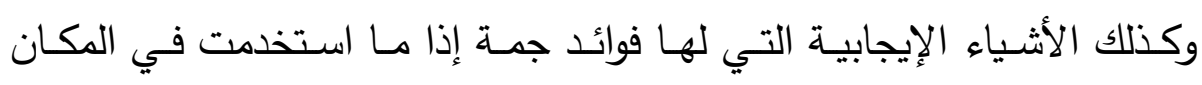
المخصص لها. • للتربية أثر واضح في كل مراحل نمو الفرد.

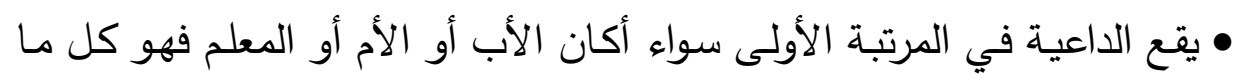

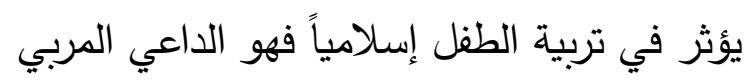




\section{|لنُوصيانه:-}

ا- على المـربين أن يقتدوا بـالمنهج الإسـلامي في التربيـة وألّا ينشـغلوا بالـنيا ويتركوا تربية أولادهم دون مراعاة لحق الله تعالى عليهح في تربيتهم, وأن يكونوا

$$
\text { نعم الآباء والأمهات والإخوان والأصدقاء. }
$$

r - عدم رفض العولمة لأنه لا يمكن أن يعيش المسلمون في معزل عن العالم ولكن يجب أن يأخذوا الجوانب المفيدة منها ويسخروا طاقاتهم وجهودهم في

$$
\text { صد الجوانب المدمرة. }
$$

ب- صحوة اللدعاة والمفكرين وانتباههم لما يحيط بهم من أخطار حول الإسـلام والمسلمين والثباب.

ع - إدخال عقيدة راسخة في قلب الأبناء وذلك باستخدام الأدلة البديهية الفطريـة

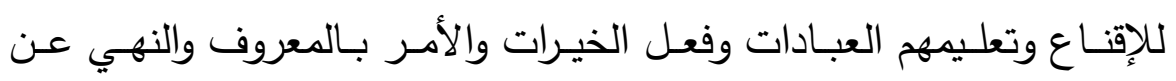

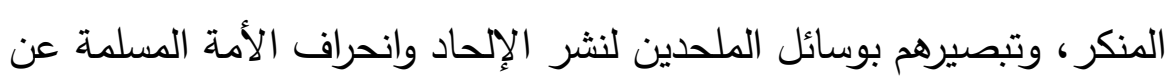

\section{غاياتها.}

ه- لابد للداعية من الاستفادة من علوم التربية وخبرات المربين وتجاربهم العديدة

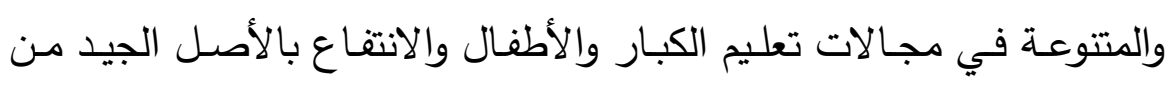
أصول التربية وطرائقها في التأثير على عقولهم وعواطفهم وإثارة حوافز الخير في أنفسه ومطاردة نوازع الثر بين خباياهم مع وجوب الاحتراز من النزعات الهدامة والشطحات المتطرفة في الفلسفات الحديثة المعاصرة.

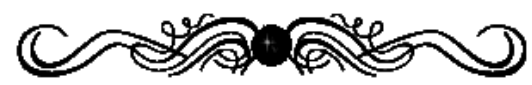




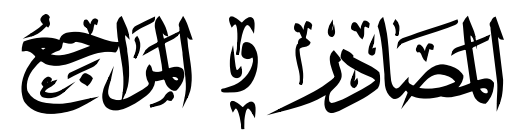

القران|لكريم:

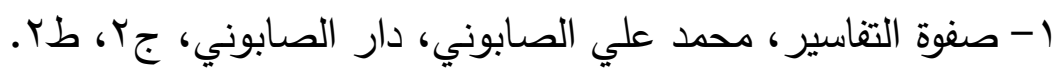

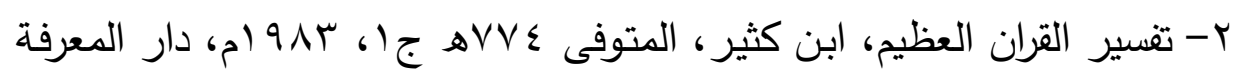

$$
\text { بيروت - لبنان. }
$$

|لسنة:

ז- البخـاري، كتاب الأحكام، بـاب قول الله تعالى وأطيعوا الله وأطيعوا الرسـول

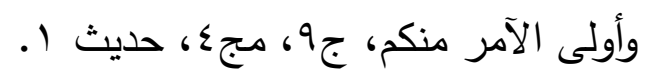

ع- صحيح البخاري، كتاب اللباس، باب المتثبهون بالنساء والمتثبهات بالرجال

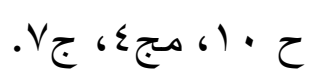

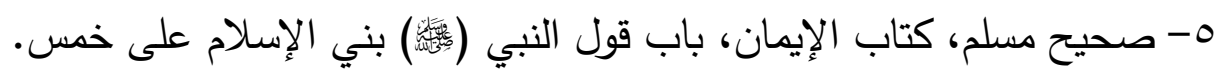
צ- سنن الترمذي، أبواب البر والصلة، باب ما جاء في حق الجوار، باب دول حديث رقم

$$
\text { . . . V }
$$

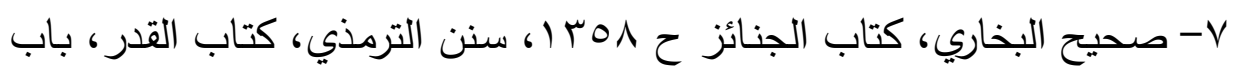

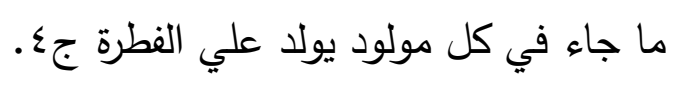

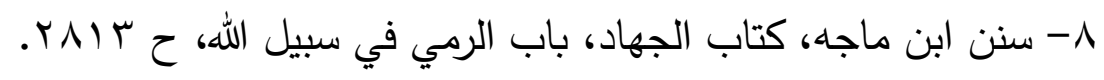

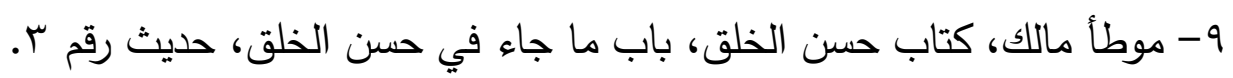

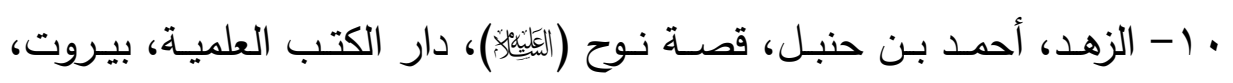

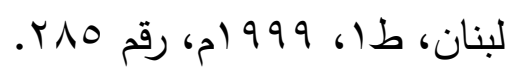

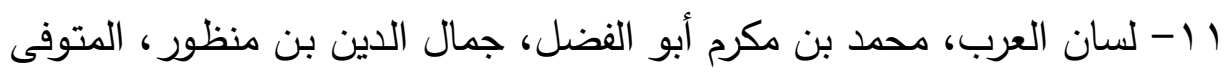

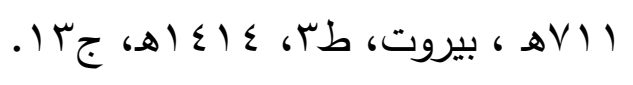


Y ا - مصحح اللغة العربية المعاصرة، أحمد مختار عبد الحميد، المتوفى ؟ ؟ اهـ

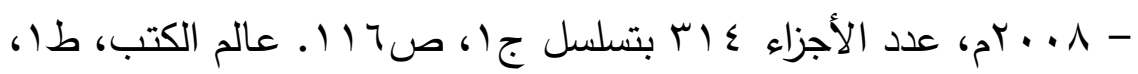

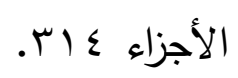

با - المصباح المنير في غريب الشرح الكبير، أحمد بن محمد علي الفيومي،

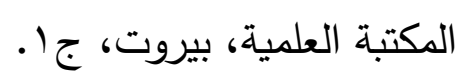

ع ا - النهاية في غريب الحديث والأثر ، مجد الدين أبو السعادات المبارك محمد

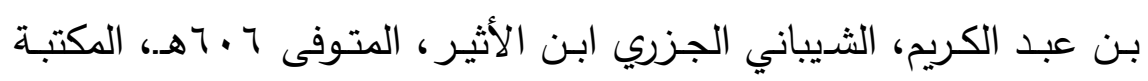
العالميـة بيروت 99س، تحقيق ظـاهر الزاوي - محمد بـن محمد الطناس

$$
\text { ج }
$$

0

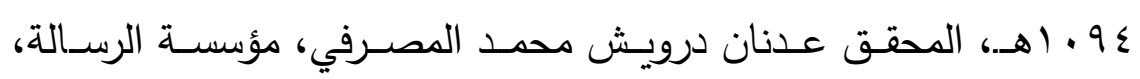

$$
\text { بيروت. }
$$

7 ا - كتاب التعريفات، الجرجاني، المتوفى 7 ا مهـ، دار لكتب العلميـة بيروت

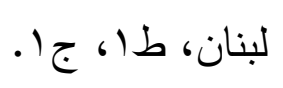

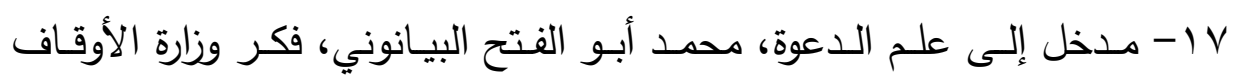

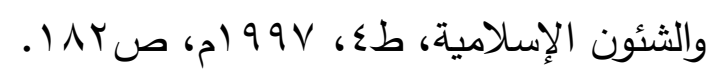

1 1 - منهج القرآن في تربية المجتمع، عبد الفتاح عاشور ، دار المكتبة الخاذجي،

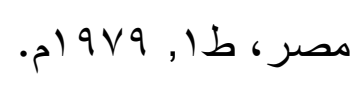

9 ( - فلسفة التربية الإسـلامية في القرآن الكربم، علي خليل أبو عينين، مكتبـة

إبراهيم علي، المدينة المنورة، طس.

• † - مواجهة العولمـة، زكريـا بشير إمام، مركز قاسم للمعلومات والخدمات، طا

$$
\text { . مr... }
$$


ا ا - الثقافة العربية في زمن العولمة، أحمد مجدي حجازي، طا، ب . . بم، دار

قباء للنشر .

r r - العولمـة قدر أم اختيار، الطيب على عبد الرحمن وزارة الثقافة والسياسـة،

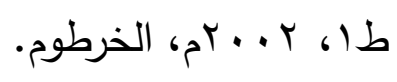

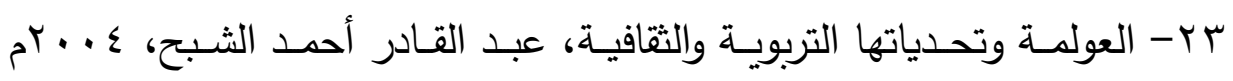
إبداع الفن للطباعة.

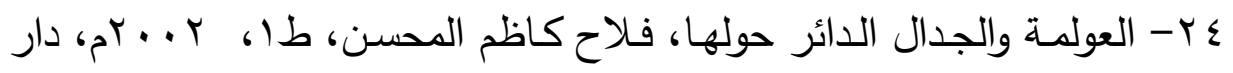
الوراق للطباعة والنشر ·

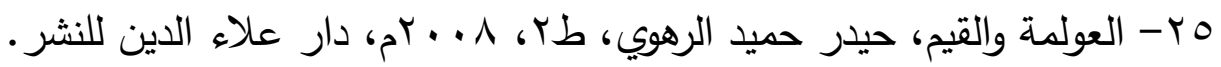
جب - التربية الإسلامية بين الأصسالة والمعاصرة، عبد الغني النووي، دار الفيحاء

طا.

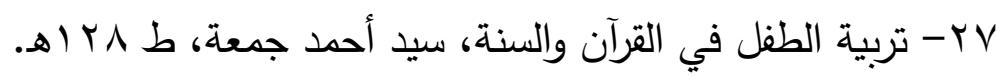

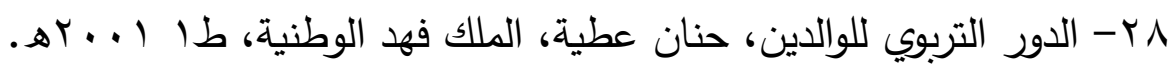
و - التربية الاسلامية بين الأصالة والمعاصرة، عبد الغني النووي، در الفيحاء.

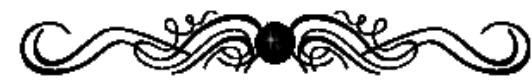




\section{فهرس الأوضومات}

\begin{tabular}{|c|c|}
\hline 110 & ملخص البحث \\
\hline 117 & الملخص إنجليزي \\
\hline 118 & المقدمة \\
\hline 111 & الاراسات السابقة \\
\hline 119 & المبحث الأول: المعنى اللغوي والاصطلاحي للتربية والأبناء واللاعوة \\
\hline $1 Y 7$ & المبحث الثاني: القواعد الدعوية للتربية وأهميتها \\
\hline Iro & المبحث الثالث: نماذج التربية الدعوية للأبناء في القرآن والسنة \\
\hline $1 \leq \varepsilon$ & المبحث الرابع: تحديات التربية المعاصرة وطرق معالجتها دعوياً \\
\hline 101 & 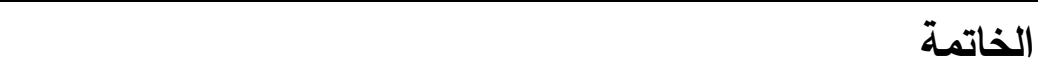 \\
\hline 10r & 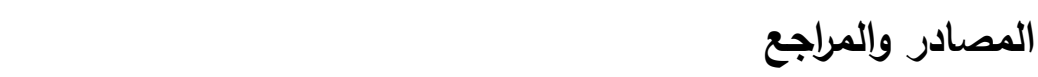 \\
\hline 107 & فهرس الموضوعات \\
\hline
\end{tabular}

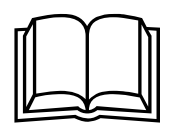

